\title{
Archaeobotany of Brazilian Indigenous Peoples and Their Food Plants
}

\author{
Mariana Franco Cassino, Myrtle P. Shock, Laura Pereira Furquim, \\ Daniela Dias Ortega, Juliana Salles Machado, Marco Madella, \\ and Charles R. Clement
}

\section{Contents}

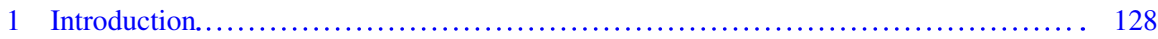

2 The Long-Term Mutualistic Relationships Between Indigenous Peoples and Plants..... 130

3 Cultural Meals and Cultural Landscapes..................................... 131

4 Archaeobotany: Tools for Assessing the Long-Term History of Food Plant

Consumption and Management............................................ 132

5 Food Plant Remains in Brazilian Archaeological Sites............................... 135

$5.1 \quad$ Rock Shelters....................................................... 135

5.2 Coastal and Fluvial Shell Mounds............................................... 137

5.3 Open-Air Sites in Brazilian Amazonia.......................................... 139

M. F. Cassino $(\square)$

Programa de Pós-Graduação em Botânica, Instituto Nacional de Pesquisas da Amazônia (INPA), Manaus, Brazil

ICREA - CaSEs - Department of Humanities, Universitat Pompeu Fabra (UPF),

Barcelona, Spain

M. P. Shock

Programa de Antropologia e Arqueologia, Instituto de Ciências da Sociedade, Universidade Federal do Oeste de Pará (UFOPA), Santarém, Brazil

L. P. Furquim

Museu de Arqueologia e Etnologia, Universidade de São Paulo (USP), São Paulo, Brazil

e-mail: laura.furquim@usp.br

D. D. Ortega $\cdot$ M. Madella

ICREA - CaSEs - Department of Humanities, Universitat Pompeu Fabra (UPF),

Barcelona, Spain

e-mail: daniela.dias01@estudiant.upf.edu; marco.madella@upf.edu

\section{J. S. Machado}

Departamento de História, Universidade Federal de Santa Catarina (UFSC),

Florianópolis, Brazil

e-mail: juliana.salles.machado@ufsc.br

C. R. Clement

Coordenação de Tecnologia e Inovação, Instituto Nacional de Pesquisas da Amazônia (INPA), Manaus, Brazil

e-mail: cclement@inpa.gov.br 
5.4 Pit Houses in the Southern Brazilian Highlands............................. 141

6 Brazilian Food Plants and Their Migrations...................................... 143

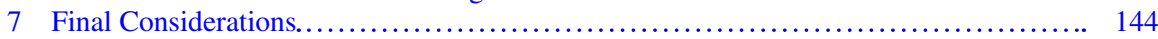

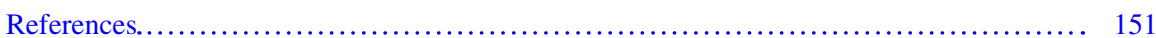

\section{Introduction}

Human history in Brazil began at least 25,000 years ago (Lahaye et al. 2015; Vialou et al. 2017). Through the millennia, human societies organized and reconfigured their social and political organizations. They also had diverse bodies of knowledge that were shared by people within the society, including their experiences and practices related to plant and landscape management. The breadth of plant food use in Brazil is explained not only by the great local biodiversity and the heterogeneity of Brazilian biomes but also by diverse long-term indigenous food choices.

Archaeological sites are places where material evidence of human occupations, such as ceramic and stone artifacts, plant remains, animal and human bones, earthworks, and/or rock art can be found, and their investigation is fundamental to the reconstruction of human histories. Although it is often difficult to link archaeological sites to modern or historically documented indigenous populations, a notion of the cultural diversity that created the archaeological record can be glimpsed through linguistic diversity (Fig. 1). Current linguistic diversity in Brazil includes more than 160 languages from 39 families. However, pre-Columbian linguistic diversity could have been at least six times higher (ISA 2020). It is notoriously difficult to estimate the population of indigenous groups in the Americas prior to European invasion due to the subsequent loss of lives to wars, epidemic diseases, and slavery. Denevan (1992), a geographer, estimated that there were 24.3 million inhabitants in South America, and this number is similar to a more recent review estimating their numbers at 23.6 million (Koch et al. 2019). Across Brazil there were thousands of indigenous communities of different sizes, economic practices, and social and political organizations. European invasion brought to an end, or significantly changed, most of these communities and their practices as they fled colonization and, in some cases, merged following population losses and/or for greater defensive power (Hemming 1995). The losses of human lives and populations led to the disappearance of some traditional ecological knowledge, and many cultivated plants, yet, great agrobiodiversity remains (Clement 1999).

Food consumption permeates practically all daily and ritual activities of human life and thus strongly influences how people interact with their environments and transform them. Over the long term, these varied dynamics contributed to the formation of Brazilian landscapes and their agrobiodiversity. This chapter will explore the diversity and temporality of food plant use documented in the archaeological record, including the expansion of different crops across the continent and how foodways have been, and continue to be, crucial to the creation of current landscapes. 


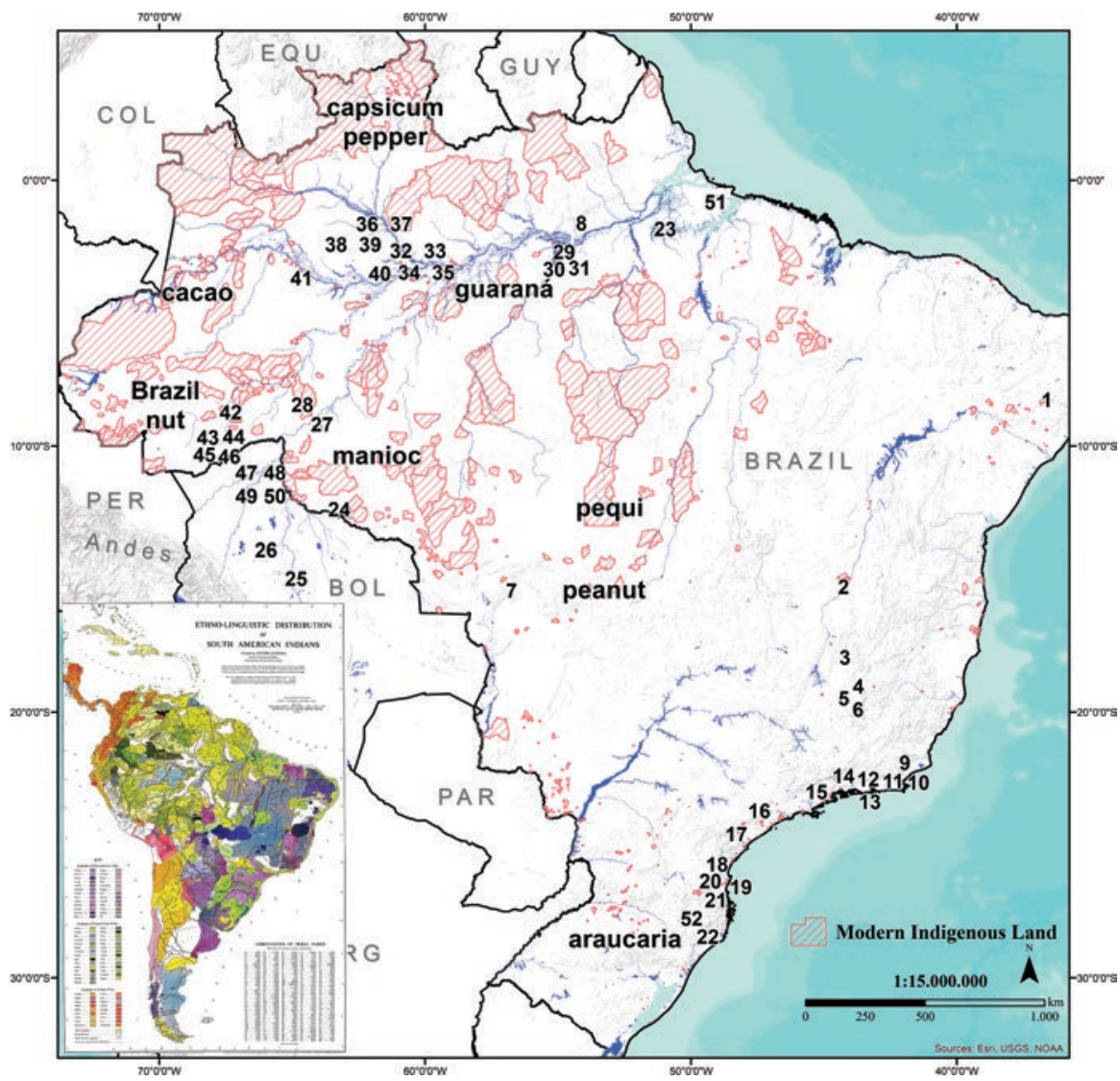

Fig. 1 Locations of archaeological sites (numbered) and the centers of origin for some native crops, by name, within Brazilian territory with respect to the locations of modern indigenous lands (FUNAI 2020). Historical ethnic and linguistic diversity among South American indigenous people is shown below and to the left based on the Ethno-linguistic Distribution of South American Indians, compiled by Čestmir Loukotka (1967) and used with permission from Taylor \& Francis. Archaeological sites are: Rock shelters: 1. Furna do Estrago, 2. Santana do Riacho, 3. Lapa do Santo, 4. Lapa dos Bichos, 5. Lapa Pintada, 6. Lapa Grande de Taquaraçu, 7. Santa Elina, 8. Pedra Pintada; Shell mounds: 9. Sambaqui Salinas Peroano, 10. Sambaqui Ponta da Cabeça, 11. Sambaqui Boca da Barra, 12. Sambaqui Beirada, 13. Sambaqui Pontinha, 14. Sambaqui do Meio, 15. Sambaqui do Forte, 16. Moraes, 17. Capelinha, 18. Enseada I, 19. Forte Marechal Luz, 20. Morro do Ouro, 21. Itacoara, 22. Jabuticabeira II, 23. Tucumã, 24. Monte Castelo, 25. Isla del Tesoro, 26. Isla Manechi; Open-air sites: 27. Teotônio, 28. Santa Paula, 29. Serra do Maguari-1, 30. Lago Caranã, 31. Cedro, 32. Hatahara, 33. Açutuba, 34. Lago Grande, 35. Osvaldo, 36. Vila Nova I, 37. Vila Nova II, 38. Floresta, 39. Lago das Pombas, 40. Caldeirão, 41. São João, 42. Cruzeirinho, 43. Fazenda Iquiri II, 44. Sol de Maio, 45. Campo Esperança, 46. Tequinho, 47. El Círculo, 48. Las Palmeras, 49. Chacra Talería, 50. Tumichuchua, 51. Aterro dos Bichos; Pit house: 52. Bonin. Designed by Laura P. Furquim 


\section{The Long-Term Mutualistic Relationships Between Indigenous Peoples and Plants}

Human populations that arrived in lowland South America about 25,000 years ago accumulated knowledge about the flora and fauna of the areas that they settled and perfected practices that aided in the exploitation of these resources. The variation in size, color, sweetness, and flavor in any population of edible plants would have been observed and humans selected their preferred types. Once plant resources are identified as food, or favored types of that food, they can be protected, which can involve the removal of plants competing for light and nutrients. Future harvests are also enhanced when picked fruits, nuts, or tubers are transported back to the settlement for processing or for sharing with other members of the group, as along the trail some may fall from the basket or the seeds of consumed fruits may be discarded. Both fallen fruits and discarded seeds may germinate along the route or in the camps and establish new populations. These may eventually be exploited and also protected by human groups using the trails. Over time this may lead to trails enriched with useful plants and the progressive movement of favored plants from their original populations. Since any settlement is surrounded by trails leading to important food resources, they are central to the development of a mosaic of domesticated landscapes with enhanced availability of different food plants. These are culturally constructed niches within ecosystems that continue to experience natural transformations (Smith 2012; Clement and Cassino 2018).

Over millennia, in different intensities, these transformational dynamics instigated by human groups eventually altered the abundance and distribution of many plant populations in Brazilian biomes, most notably the populations of useful trees that occur in stands (Levis et al. 2018; Balée 1989, 2013). In Amazonia, the most emblematic stands are those of Brazil nut (Bertholletia excelsa Bonpl.), the castanhais (Shepard Jr. and Ramirez 2011), but there are many others (Levis et al. 2018). Pequi (Caryocar brasiliense Cambess.) stands occur across the Cerrado (a region with savanna-like vegetation), and those in the upper Xingu River are domesticated (Fig. 1) (Smith and Fausto 2016). In the Atlantic Forest, araucaria (Araucaria angustifolia (Bertol.) Kuntze) can occur in immense stands, many of which are directly connected to indigenous activities (Bitencourt and Krauspenhar 2006; Reis et al. 2014). The importance of such tree stands as food resources is huge; for Amazonia, Clement (2019) estimated that the harvest from six species of forest fruit trees that occur in such stands can produce more protein than all the cattle currently in Amazonia (see also Shepard Jr. et al. 2020).

All human settlements have areas where refuse is discarded (called middens by archaeologists) and which often form anthropic soils (Lathrap 1977; Erickson 2003). The by-products from plant processing would normally be deposited in these areas, and discarded seeds or vegetative parts of plants might grow, producing new resources within the settlement. These new plants could be tended and protected, which is the origin of home gardens (Lathrap 1977; Anderson 2005).

As human populations grew during the Holocene, the number and size of settlements increased, many becoming permanent, and each was surrounded by an 
expanding mosaic of domesticated landscapes. When the food requirements of a community increased, this could be obtained by expanding the gardens further, even beyond the nutrient-rich soils of the middens. This expansion further changed the landscape mosaic around the settlement and some areas were more intensively managed with the production of annual, semi-annual, and perennial food plants (Denevan 2001). These intensively managed areas are called agroforestry systems.

Because plants anywhere in this mosaic are treated by indigenous groups as individuals, in some cases even thought of as "children" (Hastorf 1998; Machado 2012), each is carefully tended and evaluated for future propagation. The result is that some of these plant populations became domesticated over time, sometimes with remarkable differences in size, color, sweetness, and flavor compared to the wild plants of the same species (Clement 1999). The relationship between humans and their plants is mutualistic, where both populations benefit: plants are cared for and propagated, and humans gain their company and nutritional value.

\section{Cultural Meals and Cultural Landscapes}

Food ingredients are collected, produced, harvested, processed, cooked, and consumed according to the customs and practices of each human culture. The collection of these practices and their organization in specific social, political, and cultural contexts are called foodways (Staller and Carrasco 2010). Consider for a moment one plant, the peanut (the seeds of Arachis hypogaea L.), which can be consumed toasted in the shell, or as part of a peanut brittle snack (pé-de-moleque), or as peanut butter in a sandwich. While a sandwich might be consumed alone at breakfast or lunch, roasted peanuts might be consumed socially, at soccer games or with beer in a bar, and the peanut brittle is a traditional candy of June festivities in Brazil. Across cultures, people make decisions, both consciously and by habit, as to which plants became parts of their social events and their daily meals. A large number of plants that provided foods of different types - fruits, seeds, roots, spices, leaves, etc. were the focus of human interventions, and many were domesticated. Foodways are one of the daily expressions of culture, through which consumption practices are linked to choices and knowledge about plant management, production, and processing (Staller and Carrasco 2010; Graff 2018).

The awareness and knowledge of ecological relationships is specific to each ecosystem, or even local landscapes, and changes when human populations move to new ecosystems. Traditional ecological knowledge was, and is, dynamic, as it is learned not only generationally but also from personal experiences, family, and neighbors. It includes behaviors and practices of interactions with plants that favored the creation of cultural niches and landscape mosaics with enhanced food availability. Choices about the adoption of domesticated plants were different among different human cultures. It follows that domesticated plants and domesticated landscapes are cultural artifacts that were molded by each specific culture's knowledge, beliefs, values, and foodways. 
The cultivation of plants, through culturally specific ecological knowledge for culturally specific foodways, is the basis for the farming-language dispersal hypothesis (Renfrew and Bellwood 2002). The distribution of Arawak languages may be a lowland South America example of a farming-language dispersal of growing populations (Blench 2012). With information about the variation in words for the same plant among members of the Arawak linguistic dispersal, it is possible to identify a language homeland and even put a date on it. Based on the names for manioc (Manihot esculenta Crantz) and hot pepper (Capsicum spp.), both of which were domesticated in lowland South America, and maize (Zea mays L.) and common bean (Phaseolus vulgaris L.), domesticated in Mexico and the central-northern Andes, respectively, Brown et al. (2013a, b, 2014a, b) suggest that the ancestors of today's Arawak speakers had adopted each of these domesticates by $4000 \mathrm{BP}$ in western Amazonia. Thus, meals that contained an abundance of energy (manioc), a diversity of protein (maize and bean, but also fish), spiced with hot pepper may have fueled the Arawak dispersal across lowland South America and into the Caribbean. These four crops are common to other indigenous foodways, both of widely dispersed language families and of languages that did not disperse, reinforcing the observation that choices about plant cultivation are not tied to the plants, but rather to cultures.

Although anthropogenic forests occur all over Brazil, not all groups have adopted the cultivation of herbaceous plants. For example, landscape mosaics enriched with food species are created by indigenous populations with highly mobile lifestyles, such as the Nukak, that do not have cultivated fields (Politis 1996). Also, the deliberate creation of enriched forest spaces has been documented on the Southern edge of the Amazon where the Gorotire Kayapó alter the soil and soil fauna in locations that retain greater amounts of water and, into this improved ecosystem patch, plant a diversity of useful species, including foods and spices (Anderson et al. 1989; Posey 1985). In Southern Brazil, the application of ecological knowledge of araucaria included deliberate seed dispersal and increased burning to promote the expansion of araucaria nut stands (Bitencourt and Krauspenhar 2006; Reis et al. 2014). Each food plant requires local ecological knowledge that directs the management practices central to its production, processing, and consumption. Foodways continuity and variability over time and across space during the Holocene frame the histories of cultural landscapes (Cassino et al. 2019; Ingold 1993).

\section{Archaeobotany: Tools for Assessing the Long-Term History of Food Plant Consumption and Management}

Archaeobotany is the study of plant remains recovered from archaeological contexts and the human activities that they represent, including cultural foodways (Pearsall 2015; Graff 2018; Hastorf 1999). Macroscopic botanical remains include dried and charred fragments of wood (Fig. 2a, b), fruits (Fig. 2g), seeds (Fig. 2h, i), and tubers. 
The majority of archaeological charcoal is from wood and directly related to firewood preferences. Wood used as fuel can indirectly inform about diet, since it is frequently acquired from surrounding vegetation enriched with food plants. By contrast, most of the fragments of tubers, fruits, and seeds are by-products of food processing and were likely deposited in middens or burnt with other waste. For example, the hard seed coats of Brazil nuts are more likely to be found than the edible kernels (seeds). Archaeological charcoal is collected when it is visible during excavation and by sieving or flotation of excavated sediments. The screen size of the sieve determines the size of fragments that are recovered. Given the diminutive size of some seeds, most analysis is carried out on sediment samples processed through fine mesh with openings between $0.5 \mathrm{~mm}$ and $2.0 \mathrm{~mm}$ (Pearsall 2015).

Plants also leave a number of different microscopic remains. Starch grains (Fig. 2c-e) can adhere to or be incorporated into pieces of ceramics, stone tools, and tartar on human teeth (dental calculus), and, further, they can occur in coprolites (desiccated feces). Starch grains from plant species are identifiable at different taxonomic levels and may also show signs of injury from processing (e.g., grinding) and/or from exposure to heat from cooking (Henry et al. 2009). Phytoliths (Fig. 2f) are silica bodies that form in plant cells and retain the shape of these cells. They are diagnostic at different taxonomic levels as well as characteristic of different plant parts, such as squash (Cucurbita spp.) fruit rinds, maize cobs and leaves, palm leaves, or rice chaff (Oryza spp.). Phytoliths can be preserved in sediments and also in pottery, grinding stones, dental calculus, and coprolites (Piperno 2006). They have been used to document the use of plants in human diet and also to provide important clues about plant domestication and dispersal (Ball et al. 2015). The enlargement of cells in some plant tissues may accompany increased fruit/seed size that occurs in some domesticated plants (Purugganan and Fuller 2011). If these tissues are phytolith forming, the resulting "domesticated" phytoliths will also have increased in size. It follows that domestication can be tracked in the archaeobotanical record by recording variations in the size of phytoliths. This approach has been used to suggest that squash from ca. $9000 \mathrm{BP}$ in southwestern Ecuador (Piperno and Stothert 2003) and rice from ca. 4000 BP in southwestern Amazonia were undergoing domestication (Hilbert et al. 2017). Beyond direct plant remains, the types of foods that humans consumed can be assessed by the proportions of stable isotopes of nitrogen and carbon in human bones (Lee-Thorp 2008).

Information on how plant management changed plant communities can also be gleaned from the analysis of pollen from lake or waterlogged sediments. Pollen assemblages deposited in such sediments are composed of the pollen from species growing around the sampling location and/or from pollen grains transported in by water or wind. Pollen datasets can document the introduction of exogenous plants, as well as changes in the proportions of different plant taxa in the vegetation that might be due to management (Maezumi et al. 2018; Carson et al. 2014). Further, modern vegetation communities can also be considered cultural artifacts, both from centenary trees and from the offspring of plants that grew in the same area, and they can be tools to assess past vegetation (Cassino et al. 2019). 

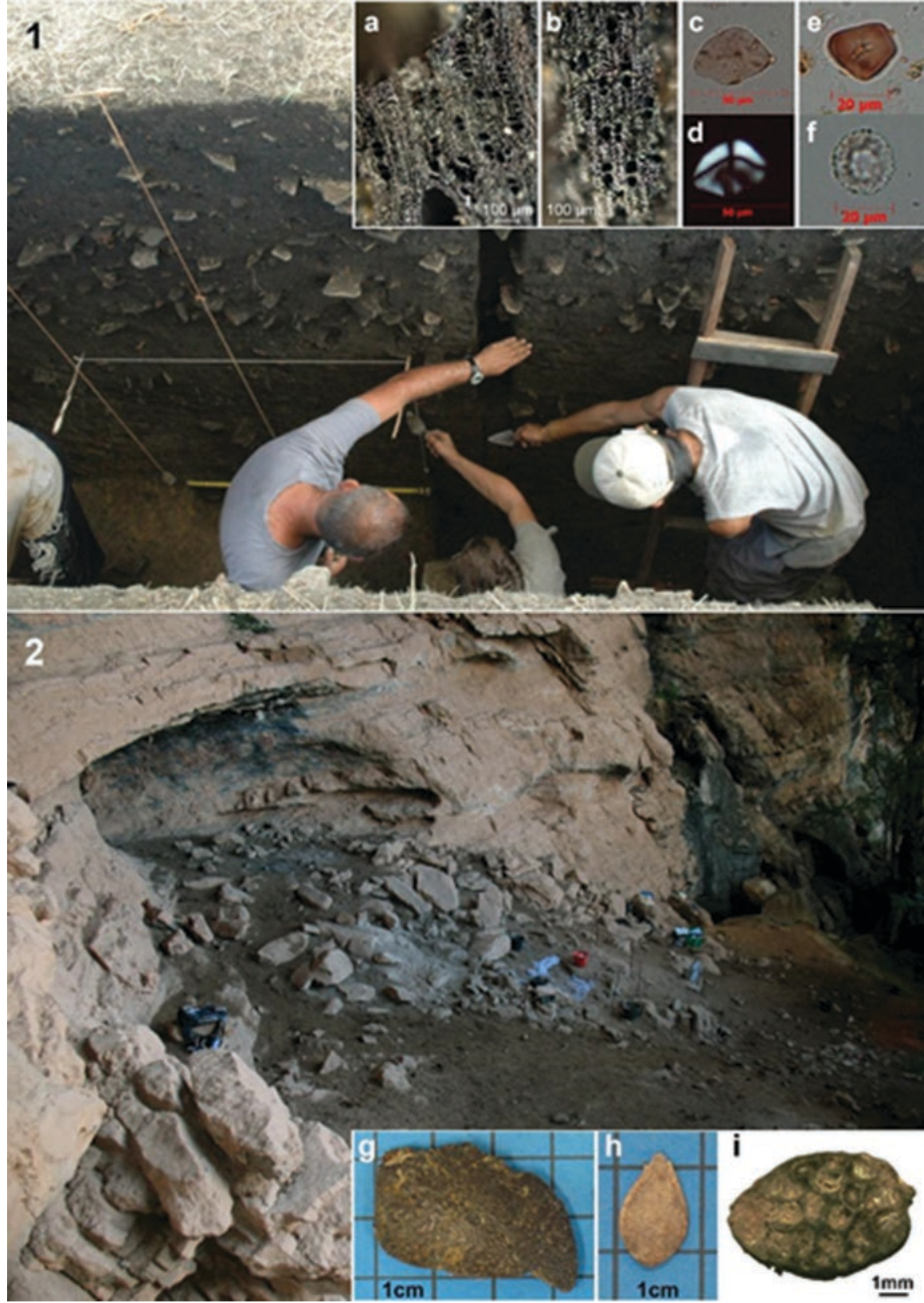

Fig. 2 Archaeological excavations at the Hatahara (1) open-air site in central Amazonia and the Lapa Pintada (2) rock shelter in the Cerrado. Examples of the diverse plant remains found are Genipa sp. (a) and Byrsonima sp. (b) wood charcoals; Dioscorea sp. (c, d) and Zea mays (e) starch grains, with (d) demonstrating the distinctive cross produced in starch by polarized light; Bactris sp. (f) phytolith; desiccated Hymenaea sp. (g) fruit rind; and desiccated Cucurbita sp. (h) and Passiflora sp. (i) seeds. [Credits: Val Moraes, Central Amazon Project (1), Caroline F Caromano (a $\&$ b), Leandro M Cascon (c-f), Myrtle P Shock $(2, \mathbf{g}-\mathbf{i})]$ 
All of these lines of evidence are complementary and refine our understanding of human diet, past, and present. Each of them has particular strengths for documenting different groups of plants: starch grains are useful to document the presence and use as food of carbohydrates-rich plant parts, especially roots, underground organs, and seeds; phytoliths are key for identifying grasses (including maize), palms, and squashes; charcoal frequently preserves identifiable characteristics of nut seed coats, some fruits, and palm seeds; pollen records catch mostly wind pollinated species, like grasses; and current vegetation often reflects plant populations that were increased in frequency and distribution by human groups, but did not become reproductively dependent on cultivation.

\section{Food Plant Remains in Brazilian Archaeological Sites}

Over the millennia of human occupation of South America, people constructed meaningful places by transforming the environment, building their homes, and attributing memories to the places they lived (Bowser and Zedeño 2009). A great diversity of cultural landscapes was created across the Brazilian biomes by past human occupations employing diverse cultural strategies. Resulting archaeological sites include rock shelters, fluvial and coastal shell mounds, open-air villages, earthworks, such as mounds and geoglyphs, and pit houses (Fig. 1). The archaeological record of foodways is a result of human practices that spanned daily activities of food production and consumption, as well as ritualistic or symbolic practices. As archaeological sites were occupied by different cultures, at different moments in time, the accumulated plant remains may reflect different practices of plant management, social contexts, and symbolic events (Klokler 2012). Further diversity is introduced by the local environment and temporal adoption of different foods. Here, we present archaeobotanical evidence of the use of food plants from sites across Brazil to highlight the diversity of foodways (see Table 1 for species information by site), histories of plant and landscape domestication, and human-mediated plant migrations. In this chapter, the chronological subdivisions of the Holocene follow Walker et al. (2018): Early Holocene ca. 11,700 BP to ca. 8300 BP, Middle Holocene ca. 8300 BP to ca. $4200 \mathrm{BP}$, and Late Holocene ca. $4200 \mathrm{BP}$ to present.

\subsection{Rock Shelters}

Across Brazil, and the world, rock shelters often provide privileged records of human plant use due to the exceptional conditions of preservation. These are protected spaces of variable size in rock outcrops that were/are used for daily or specialized activities (Fig. 2.2). They may contain components of cultural communication in the form of rock art and frequently have archaeological deposits with extensive chronologies due to recurrent utilization. Within the geographic lay 
of the land, rock shelters are permanent and frequently occur on hillsides, such that those people within would have greater visibility of the surrounding area. Brazilian rock shelters that have been studied archaeologically with botanical analyses are located in the savanna (Cerrado), the northeastern semi-arid shrubland (Caatinga), and eastern Amazonia.

The recurrent use of rock shelters by diverse human populations contributes to the long-term records of plant food use dating back to at least 12,000 years ago in Brazil. From between 12,000 and 9000 BP, people living at the Pedra Pintada rock shelter in eastern Amazonia (Pará state) consumed over a dozen different types of palm and tree fruits, including moriche/buriti (Mauritia flexuosa L.f.), tucumã (Astrocaryum vulgare Mart.), Brazil nut, nance (Brysonima spp.), and jutaí/jatobá (Hymenaea spp.) (Shock and Moraes 2019; Roosevelt et al. 1996; Roosevelt 1998). By the Late Holocene, cultivated maize and squash were introduced and the number of tree crops also increased to include cashew (Anacardium occidentale L.), hog plum (Spondias mombin L.), açaí (Euterpe oleracea Mart.), among others (Table 1) (Roosevelt 2000). Resource diversity is not only observed in remains of seeds and fruits. In the Caatinga, at the site of Furna do Estrago (Pernambuco state), human coprolites revealed the presence of phytoliths from a psychoactive plant (Anadenanthera colubrina (Vell.) Brenan) and starch from a bromeliad, macambira (Bromelia laciniosa Mart. ex Schult. \& Schult.f.) (Santos 2014). Current indigenous groups produce flour from the leaves of this bromeliad to make a kind of bread, a practice that seems to have a deep history starting two thousand years ago, alongside the consumption of cultivated maize, manioc, and sweet potato (Ipomoea batatas (L.) Lam.).

Exceptional preservation can also lead to the identification of a greater variety of plants, including spices and other non-calorific plant parts, which may have been used less frequently. In the Cerrado of the state of Minas Gerais, dried plant remains from bowl-shaped pits included hundreds of pieces from a diversity of seeds and fruits that are not used in current diets, such as olho-de-boi (Mucuna sloanei Fawc. $\&$ Rendle), many of which have yet to be identified (Shock 2010). Also in the Cerrado, remains of pollen in coprolites and charcoal of seeds, fruits, and wood from late Holocene occupations in Santa Elina (Mato Grosso state) inform about food diversity in the diet and surrounding vegetation. The occurrence of manioc pollen suggests local plant cultivation alongside the consumption of babassu (Attalea speciosa Mart. ex Spreng.) and uricuri (Attalea phalerata Mart. ex Spreng.) palm nuts, and fruits like hog plum, jutaí/jatobá, ice-cream-bean (Inga spp.), and Annonaceae species (Chaves 2005; Scheel-Ybert and Solari 2005).

Beyond assessing agrobiodiversity, rock shelters with long depositional sequences allow for the tracing of chronological changes in material culture and the use of plants. The introduction of cultivated plants, for instance, may lead to new foods and ways of preparing them, as well as new choices about the management of such plants. These changes can be gradual or abrupt. In the state of Minas Gerais, the remains of seeds and fruits from the sites of Lapa dos Bichos and Lapa Pintada (Fig. 2.2) demonstrate the gradual adoption of cultivated plants arriving from other areas. This process starts with manioc and bottle gourds (Lagenaria siceraria 
(Molina) Standl.) at ca. 4300 BP, followed by maize at ca. 2000 BP, and peanut, squash, and beans from ca. 750 BP (Shock et al. 2013). In the same region, microbotanical remains from Early Holocene stone tools from Lapa Grande de Taquaraçu and Lapa do Santo attest to the use of stone artifacts for processing plants rich in carbohydrates, even though the taxonomic association of many starch grains is still unclear (Angeles Flores 2015; Angeles Flores et al. 2016; Ortega 2019). At Lapa do Santo, the starch grains are probably from sweet potatoes and yams (Dioscorea sp.), accompanied by phytoliths from palms, bamboos, and possibly Zingiberales rhizomes, between 12,700 and 8000 BP (Ortega 2019).

Some of the plants recovered from rock shelters are not the result of food-related daily practices. One such example is Scleria spp. in the archaeological sites of Lapa dos Bichos, Lapa Pintada, and Pedra Pintada, where the seeds were used as beads (Shock 2010). Archaeobotanical analyses of some of these types of remains can contribute to understanding plants as representations in exceptional activities. In the state of Minas Gerais, many of the rock shelters have human burials. Early Holocene burials from Santana do Riacho contain food plant remains from jatobá (Hymenaea courbaril L.), pequi, and two types of palms that researchers suggest might either have been consumed during rituals in connection with the burial or included as accompaniments for the dead (Resende and Prous 1991).

\subsection{Coastal and Fluvial Shell Mounds}

Shell mounds are archaeological sites formed mainly through the intentional accumulation of shells and sediments, and they also contain faunal and floral remains, cultural artifacts, hearths, and human burials. They were constructed and occupied by populations that were fishing, hunting, collecting, and cultivating plants and used the mounds for marking their identity on the landscape, for dwelling, camping, and for mortuary practices (Scheel-Ybert et al. 2003; Gaspar et al. 2008; Villagran 2010; Klokler 2012; Figuti et al. 2013; Pezo-Lanfranco et al. 2018).

In Brazil, shell mounds, or sambaquis, occur along the entire Atlantic coast, both near the coastline and in lagoons and estuaries, from the south of the state of Rio Grande do Sul to the state of Amapá (Imazio da Silveira and Schaan 2005). There are also fluvial sites, located along rivers in multiple drainage basins, notably from Amazonia and the Atlantic Forest. Choice of site locality was influenced geographically by the seasonality of river floods or tidal ebb. Shell mounds are diverse in relation to their antiquity, location, and material culture: the oldest ones in Brazil date from the transition from the Early to the Middle Holocene (Eggers et al. 2011; Pugliese et al. 2018), but different human groups occupied these landmarks until the colonial period (Bandeira 2013). Along the south coast of Brazil there are monumental shell mounds, e.g., Jabuticabeira II, that measures 400 x $250 \mathrm{~m}$ (approximately 9 soccer fields) and is $6 \mathrm{~m}$ high (that of a standard two-story home) (Villagran 2010), as well as very low sites. Some shell mounds present artifacts mainly from stone tool industries, while others also have large numbers of ceramic vessels. The 
inhabitants of the shell mounds had foodways based on a diverse and rich diet (e.g., Colonese et al. 2014).

Analyses of human dental calculus from shell mounds along the northern coast of Santa Catarina (Enseada 1, Itacoara, Morro do Ouro, Forte Marechal Luz, and Jabuticabeira II) revealed evidence for the consumption of maize, sweet potatoes, yams, palm fruits, and araucaria nuts during the late Holocene (Wesolowski et al. 2007; Wesolowski et al. 2010; Boyadjian 2012; Boyadjian et al. 2016). Starch grains from Jabuticabeira II show evidence of damage, supporting the functional identification of polished stone artifacts as tools for macerating plant parts (Boyadjian 2012; Boyadjian et al. 2016). On the coast of the state of Rio de Janeiro, wood charcoal found in middle and late Holocene shell mounds (Forte, Salinas Peroano, Boca da Barra, Ponta da Cabeça, Beirada, and Pontinha) belong to many taxa that produce edible fruits (Table 1), such as Byrsonima sp., Pouteria sp., and Mouriri sp. (Scheel-Ybert 2000; Scheel-Ybert and Gaspar 2014), which suggests that firewood acquired in the surrounding domesticated landscapes reflects plants that were also used as food.

Fluvial shell mounds are constructed by the accumulation of terrestrial mollusks (Megalobulimus spp. or Pomacea spp.) and are generally of smaller dimensions than the coastal ones. In the state of São Paulo, ca. $60 \mathrm{~km}$ from the coast, carbon and nitrogen isotopes extracted from human bones found in burials at the Capelinha and Moraes sites, and dating from the early and middle Holocene, respectively, indicate a diet based on terrestrial fauna, with contributions from plants with a $\mathrm{C}_{3}$ isotopic signature, which may include tubers, legumes, and many shrubs and trees (Eggers et al. 2011; Colonese et al. 2014). Further analyses at Moraes were carried out on phytoliths and starch grains from dental calculus that indicate the consumption of starchy plants, including yams and sweet potatoes (Boyadjian 2007).

In Amazonia, fluvial shell mounds contain the earliest ceramic remains in South America, anthropic soils, and some of the oldest remains of cultivated plants. They are concentrated in three areas: (i) at the mouth of the Amazon River, on Marajó Island, and in coastal estuaries from present-day French Guiana to the state of Maranhão; (ii) in the region between the floodplains of the Amazon, Tapajós and Xingu rivers; and (iii) in the seasonally flooded savannas of southwestern Amazonia, between the Guaporé wetlands and the Bolivian Llanos de Mojos (Lombardo et al. 2013; Hilbert et al. 2017; Watling et al. 2018; Furquim et al. 2021).

Bolivian shell mounds revealed the early consumption of manioc, leren tubers (Calathea sp.), and squash dated to ca. 10,500 BP (Lombardo et al. 2020), which supports genetic studies that posit southwestern Amazonia as a center for early plant domestication and experimentation (Clement et al. 2016). On the Brazilian side of the seasonally flooded savannas, the inhabitants of the Monte Castelo shell mound (middle to late Holocene) managed different ecosystems, such as forests and savannas, which supplied tree species, such as Brazil nut, nance, and cacao relatives (Theobroma sp.), as well as palms, such as tucumã (Astrocaryum sp.) and moriche/ buriti (Furquim et al. 2021). From ca. 5800 BP, they also began to consume squash, maize, and wild rice (Oryza sp.). Over time, these groups developed strategies for harvesting and selecting native Amazonian rice, characterizing the beginning of its 
domestication (Hilbert et al. 2017). The cultivation of such species is influenced by their ecology and the local seasonality: rice could be managed during the flood and harvested as waters began to recede, whereas maize and squash could be grown on mounds or following the receding flood waters.

On Marajó Island, the Tucumã shell mound shows two distinct late Holocene diets, the first associated with shell rich sediments and the second with anthropic soils. The first occupation, dated from 4400 to $1600 \mathrm{BP}$, and associated with the earliest ceramics of the region, has a phytolith assemblage showing that maize and squash were consumed from the beginning of the occupation (Hilbert 2017). Maize, however, is not present in the later occupation with anthropic soils and dated to 1600 BP. These changes in diet also included a lower presence of squash phytoliths with sizes comparable to domesticated squash and the increasing presence of palm phytoliths. Hilbert (2017) suggests that these changes are connected to a shift in food production strategies and the incorporation of palm species in dietary practices. At Tucumã shell mound, wild rice was present in the landscape, as evidenced by rice phytoliths in natural soil profiles, but contrary to what happened at Monte Castelo, it was not domesticated or incorporated into the local diet (Hilbert 2017).

The diversity in the adoption of plants within regional diets, as exemplified by the adoption of rice at Monte Castelo and not at Tucumã, even when available in the ecological settings, highlights that specific food choices are related to local social practices. Some shell mound occupations present evidence for cultivation and consumption of a select range of species, while others present stronger tendencies for the use of a wide variety of plants.

\subsection{Open-Air Sites in Brazilian Amazonia}

Over 6500 archaeological sites have been identified in Brazilian Amazonia to date. The first records of human populations in the region date back to $14,000 \mathrm{BP}$, although the last two millennia showed a considerable increase in human occupations (Tamanaha 2018). Most Brazilian Amazonian sites were open-air villages, some of them including earthworks, such as the geoglyphs of Southwest Amazonia and the tesos (earthen mounds) of Marajó Island. More than half of Amazonian sites have anthropic dark earths (ADEs; Fig. 2.1) (Tamanaha 2018), soils formed by the disposal of organic waste in middens, which mark long human permanence and high population density (Arroyo-Kalin 2017; Neves and Petersen 2006). These soils appear in archaeological sites in great frequency starting ca. $3000 \mathrm{BP}$; however, there is evidence of ADEs from ca. 7500 BP in the upper Madeira River (Zuse 2014).

At the Teotônio site, along the upper Madeira River, where human occupation was continuous for almost 10,000 years, phytoliths from the early and middle Holocene identified the early presence of cultigens, such as manioc, squash, beans, and other roots and tubers (Watling et al. 2018). Dating to the same period, archaeobotanical evidence of edible fruits such as piquiá (Caryocar sp.), Brazil nut, guava (Psidium sp.), and several palm genera demonstrate that local foodways also 
depended upon fruit and nut trees (Watling et al. 2018). Since culture is highly dynamic, local plant exploitation strategies and foodways varied during the longterm human occupations of the site, and new crops, such as maize, sweet potato, yam, and arrowroot, were introduced during the late Holocene (Watling et al. 2020).

Crop cultivation was an important source of food in Amazonia, even in interfluvial areas without dark earths. At geoglyphs in the upper Purus River basin, phytolith analysis of sediments from the last 1500 years of pre-Columbian occupation shows that local foodways were based on the consumption of different parts of non-woody plants and shrubs, both cultivated and not, including maize, squash, Heliconia sp., and Celtis sp. (Watling et al. 2015), as well as fruit trees and palms, such as Brazil nut, hog plum, uricuri, and peach palm (Bactris gasipaes Kunth) (Pärssinen et al. 2020). The considerably smaller size of archaeological fruits of Brazil nut and uricuri, compared to modern ones, suggests a continuous selection for larger fruits over time, in a long process of coupled plant and landscape domestication (Pärssinen et al. 2020).

The combination of food production systems and the exploitation of plants along forest trails transformed the Amazonian landscapes (e.g., Watling et al. 2017). Today, the richness and abundance of domesticated trees and palms is higher around Amazonian archaeological sites (Levis et al. 2017). In the lower Tapajós River, for example, agroforestry systems were developed since $4500 \mathrm{BP}$, combining the cultivation of annual crops, such as maize, sweet potato, manioc, and other roots and tubers, with the progressive enrichment of edible forest species, such as piquiá and many palms (Maezumi et al. 2018; Troufflard and Alves 2019).

Since food consumption and landscape transformations are intimately related, botanical remains from the surroundings of ancient human settlements can provide further information about local foodways. In a late Holocene occupation at the Hatahara site (Fig. 2.1) in Central Amazonia, wood charcoal from several taxa producing edible fruits, including Spondias sp., Genipa sp., and Byrsonima sp., suggest that firewood was being collected in anthropogenic environments around the village that were enriched by plants that were also used as food (Scheel-Ybert et al. 2016; Caromano et al. 2013). In the same archaeological context, phytoliths of many crops and palms, such as moriche/buriti, patauá (cf. Oenocarpus bataua Mart.), and açaí were identified (Bozarth et al. 2009; Caromano et al. 2013; Cascon 2010).

At many other late Holocene Amazonian sites, the remains of cultigens, such as maize and tubers, are generally found together with a broad variety of fruit species, especially palms (Silva et al. 2016). In Central Amazonia, at the Caldeirão site, manioc and maize were identified in association with palm remains, notably peach palm. In the middle Solimões River, Brazil nut, cacao (Theobroma sp.), tucumã (Astrocaryum sp.), and other fruits were found in association with maize cultivation (Cassino 2018). Brazil nut is widespread in the archaeological record, as it is also found in the lower Rio Negro, the middle Rio Unini, and the lower Amazon (Shock et al. 2014). In Eastern Amazonia, on Marajó Island, açaí, tucumã, Inga spp., and Sterculia spp. were consumed (Roosevelt 1989). 
Archaeobotanical data suggest that, since the beginning of human occupation in Amazonia, people started managing native fruit species and, very early on, initiated the dynamics that eventually brought about the domestication of numerous species (Roosevelt et al. 1996; Shock and Moraes 2019; Watling et al. 2018). Although in some periods a given species might have been more important in some local diets, such as manioc in the Xingu basin (Heckenberger 1998) or maize in late occupations along many Amazonian rivers (Watling et al. 2020), archaeobotanical data from Brazilian Amazonia show that pre-colonial indigenous peoples had rich and diversified diets, arising from the association of domesticated crops and a great variety of palms and fruit trees, produced in horticultural and agroforestry systems and from fruit exploitation in the forest (Shepard Jr. et al. 2020). Through thousands of years these food systems have guaranteed long-term food security despite climate and social changes (Maezumi et al. 2018).

\subsection{Pit Houses in the Southern Brazilian Highlands}

Pit houses are part of a wide range of earthwork constructions of different forms and sizes found in the Southern Brazilian Highlands, including enclosures in circular and elliptical shapes formed by causeways, mounds, as well as a variety of subterranean structures used for food processing, storage, and various types of hearths and kilns. The diameters of pit structures vary from 2 to $20 \mathrm{~m}$; however most are less than $5 \mathrm{~m}$ across. While they may occur in isolation, pit structures are normally found together in groups, some of which are composed of over a hundred structures (Corteletti et al. 2016). These archaeological sites are located on hill tops or high ridges, at elevations that vary from $600 \mathrm{~m}$ to $1800 \mathrm{~m}$. Archaeological data from several excavations in the Brazilian states of Paraná, Rio Grande do Sul, and Santa Catarina, as well as frontier regions with Argentina and Paraguay, dated the appearance of these structures to the late Holocene, ca. $2200 \mathrm{BP}$, and they were used until the colonial period (Iriarte et al. 2008). There was a peak of these settlements at ca. 950 BP, marked by population growth, more intensive food-production systems, and long-distance human migrations (Iriarte et al. 2008). These diverse archaeological structures have been associated with Southern Jê speaking indigenous populations. Their descendants are the Kaingang and the Laklãnõ Xokleng, who still live in the region today, although in restricted territories.

Sites where earthen enclosures are found are usually associated with central mounds that were used as funerary contexts (Iriarte et al. 2008). These may have been ceremonial spaces due to their formal layout and the lack of domestic remains (Iriarte et al. 2008). Symbolic consumption of a fermented beverage made from maize and honey during mourning was documented among the Kaingang people in historical accounts (Métraux 1946). Cremation practices were common among 
some of the Jê people in the pre-Columbian period and were historically documented within the Laklãnõ Xokleng before Christianization. Distinct from the mound/enclosure complexes, domestic subterranean structures have circular forms, sometimes presenting "benches" on one or more levels along the walls. Evidence for ceilings is found in postholes that mark where supporting beams entered the floor. Hearths are frequent on the lowest level of the dwellings, along with thin ceramic sherds, some stone tool remains, and charred araucaria nuts.

Archaeobotanical analysis of microscopic remains from ceramic vessels found in such domestic contexts in the Santa Catarina highlands identified the consumption of maize and other domesticated plants, such as beans, squash, and manioc (Corteletti et al. 2016). The authors suggest that the gathering of edible fruit from trees, such as goiabeira-serrana (Acca sellowiana (O.Berg) Burret), jabuticaba (Plinia trunciflora (O. Berg) Kausel), guabiroba (Campomanesia sp.), araçá (Psidium sp.), custard apple (Annona sp.), queen palm (Syagrus romanzoffiana (Cham.) Glassman), jelly palm (Butia capitata (Mart.) Becc.), and wolly jelly palm (Butia eriospatha (Mart. ex Drude) Becc.), as well as hearts of palm from juçara (Euterpe edulis Mart.) could also have had important roles in the local diet. Although these were not identified in the archaeobotanical record, they were reported as food in historical accounts about Kaingang and Laklãnõ Xokleng people (Corteletti et al. 2016). Such fruits and palms have strong cultural and symbolic significance among the Kaingang and the Laklãnõ Xokleng today. They are also indicators of their traditional knowledge of environmental management and landscape domestication. For example, for the Laklãnõ Xokleng, who live in the Upper Itajaí Valley, guava trees are important landscape references. The tree gives its name to their villages, and, in historical times, it marked the rhythm of their mobility as the cycle of fruit production played an important role in attracting game animals to feed on the fruits (Machado 2016). Knowledge about cultivated plants is also very important, as demonstrated among the Kaingang, through the existence and evaluation of origin histories (myths) for maize, beans, and squash (Borba (1908) apud Corteletti et al. 2016).

The strong relationships among indigenous cultures and their forests are well represented by another food, araucaria nuts. For modern and historically documented Southern Jê People, araucaria nuts are not only made into highly nutritious flour, bread, and beverages, but the araucaria tree has strong cultural significance (Noelli 1999; Reis et al. 2014). It is part of the process of transforming the forest in their cultural territory. The distribution of araucaria forests expanded in association with the Southern Jê populations and pit houses in pre-colonial times (Noelli 1999). Paleopalynological analyses indicate the rapid expansion of the Araucaria forests over the high grasslands between 1500 and $800 \mathrm{BP}$ (Reis et al. 2014). As mentioned earlier, this expansion was associated with cultural forest management, through transport, storage, and processing of the seeds (Reis et al. 2014), which increased the availability of this important food for the Jê populations (Iriarte and Behling 2007; Corteletti et al. 2016). 


\section{Brazilian Food Plants and Their Migrations}

In Brazil, migrations and trade among pre-colonial populations are associated with the dispersal of many plant species, such as araucaria (Iriarte and Behling 2007), Brazil nut (Shepard Jr. and Ramirez 2011), pequi (Smith and Fausto 2016), and moriche/buriti (Rull and Montoya 2014). Cacao (Theobroma cacao L.), for example, is well-known for its importance in Mesoamerica, where chocolate originated. However, its center of diversity is in western Amazonia (Fig. 1) (Thomas et al. 2012), where it is found in archaeological contexts in Ecuador from ca. 5300 BP (Zarrillo et al. 2018). The first archaeological evidence of early cacao beverages in Mesoamerica dates to before 3000 BP, in the Mayan culture (Henderson et al. 2007). Changes in the forms and decorations of Mesoamerican ceramic vessels across time suggest that beverages from cacao were initially produced by fermenting the sweet pulp surrounding the seeds, similar to the way it was consumed in Amazonia, followed later by the production of nonalcoholic chocolate beverages from fermented cacao seeds (Henderson et al. 2007).

Pre-colonial Native Americans dispersed many domesticated crops very early in time. Manioc was domesticated in southwestern Amazonia (Fig. 1) (Olsen and Schaal 1999), and its early dispersal is shown by archaeobotanical records, which date back to ca. 8000 BP in coastal Peru (Pearsall 1992) and ca. 7000 BP in Panama (Piperno and Holst 1998), and linguistic reconstructions suggest it arrived in Mexico by $6500 \mathrm{BP}$ (Brown et al. 2013b). Likewise, and in the opposite direction, maize, domesticated by 9000 BP in lowland Mexico (Piperno et al. 2009), was identified in archaeobotanical remains as early as ca. 7500 BP in Panama (Piperno et al. 1985) and ca. 6500 BP in Coastal Peru (Grobman et al. 2012) and Amazonia (Brugger et al. 2016). Genetic analyses suggest that this introduced maize further diversified in southwestern Amazonia (Kistler et al. 2018). The complex domestication history of maize is an example of how multiple waves of human-mediated dispersal can be responsible for the diversity and biogeography of many South American domesticated species. This is also the case of peanut, domesticated in Central Brazil (Fig. 1), but identified in the archaeobotanical record of early food production systems in coastal Peru, where peanut populations with a mixture of wild and domesticated features were being cultivated by 8000 BP (Piperno and Dillehay 2008).

After the arrival of European colonizers in the Americas, another series of biocultural exchanges began, leading to at least three centuries of intensive transatlantic plant migrations, which are responsible for the widespread dispersal of South American crops and spices to other continents. This process, known as the Columbian Exchange (Crosby 2003), fueled the dietary enrichment that influenced European demographic expansion, at the expense of the ethnocide of circa $95 \%$ of the Amerindian population (Koch et al. 2019). Manioc, already described as a staple food by the first European adventurers, as reported by Gaspar de Carvajal from an expedition in the Amazon River between 1540 and 1542 (Medina 1934), was one of the main cultivars traded overseas. Due to its adaptation to diverse climates, altitudes, and soils, manioc is now cultivated from the Balkans to former European 
colonies in Asia and Africa (e.g., India, Nigeria, Congo, and Mozambique). Today it is one of the most important sources of energy in many African countries (Lebot 2009).

The spread of the European world system was led by the hunt for valuable spices, foods, and medicines. Numerous Portuguese, Spanish, Dutch, French, and English commercial expeditions of the colonial period searched for the "drugs from the hinterland," American forest spices and other natural products. Among the most pursued species were the Amazonian clove or clove-wood (Dicypellium caryophyllaceum (Mart.) Nees), known since the seventeenth century for its similarity with the Indian clove (Syzygium aromaticum (L.) Merr. \& L.M. Perry); the Amazonian cinnamon or precious-bark (Aniba canelilla (Kunth) Mez), whose properties were described by the botanist Alexander von Humboldt in the XVIII century (Donini et al. 2017); and guaraná (Paullinia cupana Kunth), a stimulant domesticated by the Sateré-Mawé indigenous people, probably ca. 1000 BP in the Amazon-Tapajós interfluve (Fig. 1) (Atroch et al. 2012; Clement et al. 2010). One of the most important South American spices/vegetables that became globally prominent are the fruits and seeds of the Capsicum genus (hot and sweet peppers), including $C$. frutescens (used in Tabasco sauce), $C$. chinensis (used in curry recipes) and $C$. baccatum (popular in southern Brazil), all domesticated in Amazonia (Clement et al. 2010; Bruno 2019; Chiou and Hastorf 2014).

\section{Final Considerations}

Humans construct, modify and regulate their environments, and their experiences maintain and update traditional knowledge of the ecosystems where they live. Our species, over time, has engaged in wide-ranging environmental modifications and niche construction through our agency and cultural practices. Botanical remains from archaeological contexts across Brazil provide information about the diversity of traditional foodways and their development, which was interwoven by cultural practices into the varying ecological settings of the country. The archaeological examples demonstrate long-term histories of management practices and plant domestication, changes in uses of plant resources over time, how people's cultural choices created diverse cuisines and diets even when groups were living in similar ecosystems, and how some of these diets were based on a great variability of vegetable resources while others were more specialized on a few plants. The consumption of a variety of wild and domesticated plant resources and the processes involved with how they were/are brought into food production systems was/is informed by traditional ecological knowledge. In Brazil, the rich agrobiodiversity demonstrates how many more species were, and are, consumed by indigenous populations than those that can be found today in supermarkets. Some of these foods and spices could be more widely introduced into current foodways to be enjoyed by more people and to encourage healthier diets. 
Local food plants of Brazil are a cultural heritage. While some of this heritage is currently shared across Brazilian society, or even across the world, Brazilian indigenous peoples and traditional communities remain the essential guardians of this legacy. These peoples, through their ways of life and the knowledge accumulated over the millennia of occupation of the American continent, maintain the cultural landscapes that support this great diversity of plant foods. Therefore, they are essential to the preservation of food quality and health that are rooted in this diversity. Their agro-ecological practices, which produce agrobiodiversity and rich and resilient foodways, are in stark contrast with modern agribusinesses that are focused on monocultures, threaten biodiversity, and place a multiplicity of cultures and ways of life at great risk.

Today, the breadth and depth of the long-term relationship between indigenous peoples and plants has attracted the attention of scientists and policy makers that are interested in maintaining biodiversity and developing sustainable and resilient food production systems for future human populations. Since this territory, today called Brazil, has been occupied throughout several millennia, archaeology's contribution to a historical perspective is key to interpreting the dynamics underlying the lasting ecological changes of landscape domestication. While the archaeological record will always contain only a fraction of history and the species that were utilized, it helps us to understand long term cultural choices and their effects on the environment and to appreciate the value of producing and maintaining biological and cultural diversity.

Table 1 Food plants found in archaeological sites, ordered by the numbering used in Fig. 1. Analyzed archaeobotanical remains are identified by type: D, dried plant; NWC, non-wood charcoal; PH, phytolith; PO, pollen; S, starch; WC, wood charcoal. Radiocarbon dates are approximate and, when available, preference was given to calibrated dates. Species do not necessarily occur throughout the entire range of dates analyzed by the authors

\begin{tabular}{l|l|l}
\hline $\begin{array}{l}\text { Archaeological site - type } \\
\text { of remain (reference) }\end{array}$ & Date & Plants \\
\hline $\begin{array}{l}\text { 1. Furna do Estrago - PH, } \\
\text { PO, S (Santos 2014) }\end{array}$ & $\begin{array}{l}1860- \\
1610 \text { BP }\end{array}$ & $\begin{array}{l}\text { Herbs: Bromelia laciniosa, Ipomoea batatas, Manihot } \\
\text { esculenta, Zea mays, Solanum sp., Cucurbitaceae } \\
\text { A.Juss., Poaceae Barnhart, Solanaceae A.Juss. } \\
\text { Trees, shrubs, and palms: Anadenanthera colubrina, } \\
\text { Byrsonima sp., Eugenia } \text { sp., Licania sp., Matayba sp., } \\
\text { Neea } \text { sp., Sebastiania } \text { sp., Syagrus sp., Anacardiaceae } \\
\text { R.Br., Apocynaceae Juss., Arecaceae Schultz Sch., } \\
\text { Combretaceae R.Br., Fabaceae Lindl., Malvaceae Juss., } \\
\text { Myrtaceae Juss., Rutaceae A.Juss. }\end{array}$ \\
\hline $\begin{array}{l}\text { 2. Santana do Riacho - D, } \\
\text { NWC (Resende and Prous }\end{array}$ & $\begin{array}{l}\text { 1991) } \\
\text { BP- } \\
\text { modern }\end{array}$ & $\begin{array}{l}\text { Herbs: Lagenaria siceraria (Molina) Standl., Zea } \\
\text { mays } \\
\text { Trees, shrubs, and palms: Caryocar brasiliense, } \\
\text { Hymenaea courbaril, Oenocarpus bataua, Sterculia } \\
\text { apetala (Jacq.) H.Karst., Syagrus coronata } \text { (Mart.) } \\
\text { Becc., Astrocaryum sp., Myrtaceae }\end{array}$ \\
\hline $\begin{array}{l}\text { 2. Santana do Riacho - D, } \\
\text { NWC (Resende and Prous }\end{array}$ & 19000- & $\begin{array}{l}\text { Trees, shrubs, and palms: Sterculia apetala, Syagrus } \\
\text { coronata, Astrocaryum sp. }\end{array}$ \\
\hline
\end{tabular}


Table 1 (continued)

\begin{tabular}{|c|c|c|}
\hline $\begin{array}{l}\text { Archaeological site - type } \\
\text { of remain (reference) }\end{array}$ & Date & Plants \\
\hline $\begin{array}{l}\text { 2. Santana do Riacho - D, } \\
\text { NWC (Resende and Prous } \\
\text { 1991) }\end{array}$ & $\begin{array}{l}10,000- \\
8000 \mathrm{BP}\end{array}$ & $\begin{array}{l}\text { Trees, shrubs, and palms: Caryocar brasiliense, } \\
\text { Hymenaea courbaril, Syagrus coronata, Astrocaryum } \\
\text { sp. }\end{array}$ \\
\hline $\begin{array}{l}\text { 3. Lapa do Santo - PH, S } \\
\text { (Ortega 2019) }\end{array}$ & $\begin{array}{l}12,700- \\
8000 \mathrm{BP}\end{array}$ & $\begin{array}{l}\text { Herbs: Ipomoea batatas, Dioscorea sp., Bambusoideae } \\
\text { Luerss., Zingiberales. } \\
\text { Trees, shrubs, and palms: Arecaceae }\end{array}$ \\
\hline $\begin{array}{l}\text { 4. Lapa dos Bichos - D, } \\
\text { NWC (Shock 2010; Shock } \\
\text { et al. 2013) }\end{array}$ & $\begin{array}{l}750-150 \\
\text { BP }\end{array}$ & $\begin{array}{l}\text { Herbs: Arachis hypogaea, Manihot cf. esculenta, } \\
\text { Phaseolus vulgaris, Zea mays, Chromolaena sp., } \\
\text { Cucurbita sp., Lagenaria sp., Lasiacis sp., Passiflora } \\
\text { sp., Trichogonia sp., Eupatorieae Cass., Gnaphalieae } \\
\text { Cass. ex Lecoq \& Juill., Vernonieae Cass., Asteraceae } \\
\text { Bercht. \& J.Presl., Bromeliaceae Juss., Poaceae, } \\
\text { Solanaceae } \\
\text { Trees, shrubs, and palms: Alibertia edulis (Rich.) } \\
\text { A. Rich., Bixa orellana L., Caryocar brasiliense, } \\
\text { Guazuma ulmifolia Lam., Mucuna sloanei, Spondias } \\
\text { mombin, Spondias tuberosa Arruda, Syagrus cf. } \\
\text { oleracea, Alibertia sp., Annona sp., Byrsonima sp., } \\
\text { Ficus sp., Hymenaea sp. }\end{array}$ \\
\hline $\begin{array}{l}\text { 4. Lapa dos Bichos - D, } \\
\text { NWC (Shock 2010; Shock } \\
\text { et al. 2013) }\end{array}$ & $\begin{array}{l}2000-750 \\
\text { BP }\end{array}$ & $\begin{array}{l}\text { Herbs: Manihot cf. esculenta, Zea mays, Lagenaria } \\
\text { sp., Passiflora sp., Solanaceae } \\
\text { Trees, shrubs, and palms: Spondias mombin, } \\
\text { Spondias tuberosa, Syagrus cf. oleracea, Hymenaea } \\
\text { sp. }\end{array}$ \\
\hline $\begin{array}{l}\text { 4. Lapa dos Bichos - D, } \\
\text { NWC (Shock 2010; Shock } \\
\text { et al. 2013) }\end{array}$ & $\begin{array}{l}4250- \\
2000 \mathrm{BP}\end{array}$ & $\begin{array}{l}\text { Herbs: cf. Manihot esculenta, cf. Phaseolus lunatus, } \\
\text { Lagenaria sp., Solanaceae } \\
\text { Trees, shrubs and palms: Caryocar brasiliense, } \\
\text { Spondias tuberosa, Syagrus cf. oleracea, Hymenaea } \\
\text { sp. }\end{array}$ \\
\hline $\begin{array}{l}\text { 4. Lapa dos Bichos - D, } \\
\text { NWC (Shock 2010; Shock } \\
\text { et al. 2013) }\end{array}$ & $\begin{array}{l}6500- \\
4250 \mathrm{BP}\end{array}$ & $\begin{array}{l}\text { Herbs: Poaceae } \\
\text { Trees, shrubs, and palms: Hymenaea sp., Syagrus cf. } \\
\text { oleracea }\end{array}$ \\
\hline $\begin{array}{l}\text { 5. Lapa Pintada - D, NWC } \\
\text { (Shock 2010; Shock et al. } \\
\text { 2013) }\end{array}$ & $\begin{array}{l}1200 \mathrm{BP} \\
\text { and } 800 \\
\mathrm{BP}\end{array}$ & $\begin{array}{l}\text { Herbs: Manihot cf. esculenta, Zea mays, Lagenaria } \\
\text { sp., Lasiacis sp., Passiflora sp., Vernonieae, Asteraceae, } \\
\text { Solanaceae } \\
\text { Trees, shrubs, and palms: Caryocar brasiliense, } \\
\text { Guazuma ulmifolia, Syagrus cf. oleracea, Annona sp., } \\
\text { Byrsonima sp., Hymenaea sp., Myrciaria sp. }\end{array}$ \\
\hline $\begin{array}{l}\text { 5. Lapa Pintada - D, NWC } \\
\text { (Shock 2010; Shock et al. } \\
\text { 2013) }\end{array}$ & $\begin{array}{l}4400 \mathrm{BP} \\
\text { and } 4300 \\
\mathrm{BP}\end{array}$ & $\begin{array}{l}\text { Herbs: Manihot cf. esculenta, Lagenaria sp., } \\
\text { Passiflora sp. } \\
\text { Trees, shrubs, and palms: Caryocar brasiliense, } \\
\text { Syagrus cf. oleracea, Hymenaea } \text { sp. }\end{array}$ \\
\hline $\begin{array}{l}\text { 5. Lapa Pintada - D, NWC } \\
\text { (Shock 2010) }\end{array}$ & $7000 \mathrm{BP}$ & $\begin{array}{l}\text { Trees, shrubs, and palms: Hymenaea sp., Syagrus cf. } \\
\text { oleracea }\end{array}$ \\
\hline $\begin{array}{l}\text { 6. Lapa Grande de } \\
\text { Taquaraçu - S, NWC } \\
\text { (Angeles Flores 2015; } \\
\text { Angeles Flores et al. 2016) }\end{array}$ & $\begin{array}{l}11,400- \\
9000 \mathrm{cal} \\
\mathrm{BP}\end{array}$ & $\begin{array}{l}\text { Herbs: Dioscorea sp. } \\
\text { Trees, shrubs, and palms: Arecaceae }\end{array}$ \\
\hline
\end{tabular}


Table 1 (continued)

\begin{tabular}{|c|c|c|}
\hline $\begin{array}{l}\text { Archaeological site - type } \\
\text { of remain (reference) }\end{array}$ & Date & Plants \\
\hline $\begin{array}{l}\text { 7. Santa Elina - PO } \\
\text { (Chaves 2005) }\end{array}$ & $\begin{array}{l}400 \mathrm{cal} \\
\mathrm{BP}\end{array}$ & $\begin{array}{l}\text { Herbs: Asteraceae, Poaceae } \\
\text { Trees, shrubs, and palms: Licania sp., Sebastiania } \\
\text { sp., Apocynaceae, Combretaceae, Fabaceae - } \\
\text { Mimosoideae, Melastomataceae A.Juss., Myrtaceae, } \\
\text { Rubiaceae Juss., Rutaceae }\end{array}$ \\
\hline $\begin{array}{l}\text { 7. Santa Elina - PO, WC, } \\
\text { NWC (Chaves 2005; } \\
\text { Scheel-Ybert and Solari) }\end{array}$ & $\begin{array}{l}4000- \\
2000 \text { cal } \\
\text { BP }\end{array}$ & $\begin{array}{l}\text { Herbs: Manihot sp., Bromeliaceae, Poaceae } \\
\text { Trees, shrubs, and palms: Acrocomia aculeata (Jacq.) } \\
\text { Lodd. ex Mart., Anacardium humile A.St.-Hil., Attalea } \\
\text { phalerata, Attalea vitrivir Zona, Caryocar brasiliense, } \\
\text { Dipteryx alata } \text { Vogel, Guazuma ulmifolia, Guettarda } \\
\text { viburnoides Cham. \& Schltdl., Hymenaea stigonocarpa } \\
\text { Mart. ex Hayne, Hymenaea courbaril, Protium } \\
\text { heptaphyllum (Aubl.) Marchand, Ficus sp., Inga spp., } \\
\text { Lecythis sp., Matayba sp., Neea } \text { sp., Spondias sp., } \\
\text { Anacardiaceae, Annonaceae, Apocynaceae, Arecaceae, } \\
\text { Fabaceae, Myrtaceae, Rubiaceae, Sapotaceae Juss. }\end{array}$ \\
\hline $\begin{array}{l}\text { 8. Pedra Pintada - NWC } \\
\text { (Roosevelt 1998; Roosevelt } \\
\text { et al. 1996; Shock and } \\
\text { Moraes 2019) }\end{array}$ & $\begin{array}{l}12,400- \\
9000 \text { cal } \\
\text { BP }\end{array}$ & $\begin{array}{l}\text { Trees, shrubs, and palms: Astrocaryum vulgare, } \\
\text { Attalea microcarpa Mart., Attalea spectabilis Mart., } \\
\text { Bertholletia excelsa, Byrsonima crispa A.Juss., } \\
\text { Hymenaea c.f. parvifolia or oblongifolia, Mauritia } \\
\text { flexuosa, Mouriri apiranga Spruce ex Triana, } \\
\text { Oenocarpus cf. bacaba, Sacoglottis guianensis Benth., } \\
\text { Talisia esculenta (Cambess.) Radlk., Vitex cf. cymosa, } \\
\text { Acrocomia } \text { sp., Astrocaryum sp., Attalea } \text { sp. }\end{array}$ \\
\hline $\begin{array}{l}\text { 8. Pedra Pintada - NWC } \\
\text { (Roosevelt 2000) }\end{array}$ & $\begin{array}{l}800-500 \\
\text { BP }\end{array}$ & $\begin{array}{l}\text { Herbs: Casimirella rupestris (Ducke) R.A.Howard, } \\
\text { Passiflora nitida Kunth, Zea mays, Cucurbitaceae } \\
\text { Trees, shrubs, and palms: Acrocomia aculeata, } \\
\text { Anacardium occidentale L., Anacardium giganteum } \\
\text { W.Hancock ex Engl., Antrocaryon amazonicum } \\
\text { (Ducke) B.L.Burtt \& A.W.Hill, Astrocaryum vulgare, } \\
\text { Attalea microcarpa, Attalea spectabilis, Bertholletia } \\
\text { excelsa, Byrsonima crassifolia (L.) Kunth, Byrsonima } \\
\text { crispa, cf. Endopleura uchi (Huber) Cuatrec., Euterpe } \\
\text { oleracea, Hymenaea courbaril, Hymenaea oblongifolia } \\
\text { Huber, Hymenaea parvifolia Huber, Mauritia flexuosa, } \\
\text { Mauritiella armata (Mart.) Burret, cf. Mezilaurus } \\
\text { itauba (Meisn.) Taub. ex Mez, Mouriri apiranga, } \\
\text { Moutabea chodatiana Huber, Norantea guianensis } \\
\text { Aubl., Sacoglottis guianensis, Spondias mombin, } \\
\text { Syagrus cocoides Mart., Talisia esculenta, Vitex } \\
\text { cymosa Bertero ex Spreng., Coccoloba sp. }\end{array}$ \\
\hline $\begin{array}{l}\text { 9. Sambaqui Salinas } \\
\text { Peroano - WC (Scheel- } \\
\text { Ybert 2000; Scheel-Ybert } \\
\text { and Gaspar 2014) }\end{array}$ & $\begin{array}{l}4800- \\
1700 \text { cal } \\
\text { BP }\end{array}$ & $\begin{array}{l}\text { Trees, shrubs, and palms: Actinostemon sp., Condalia } \\
\text { sp., Cupania sp., aff. Duguetia, Inga spp., Pouteria sp., } \\
\text { cf. Swartzia sp., Annonaceae, Arecaceae, Myrtaceae }\end{array}$ \\
\hline
\end{tabular}


Table 1 (continued)

\begin{tabular}{|c|c|c|}
\hline $\begin{array}{l}\text { Archaeological site - type } \\
\text { of remain (reference) }\end{array}$ & Date & Plants \\
\hline $\begin{array}{l}\text { 10. Sambaqui da Ponta da } \\
\text { Cabeça - WC (Scheel- } \\
\text { Ybert 2000; Scheel-Ybert } \\
\text { and Gaspar 2014) }\end{array}$ & $\begin{array}{l}3450- \\
2000 \text { cal } \\
\text { BP }\end{array}$ & $\begin{array}{l}\text { Trees, shrubs, and palms: Actinostemon sp., } \\
\text { Byrsonima sp., Condalia } \text { sp., Cupania sp., aff. } \\
\text { Duguetia, Inga sp., Pouteria sp., Zollernia sp., } \\
\text { Arecaceae, Chrysobalanaceae R.Br., Myrtaceae }\end{array}$ \\
\hline $\begin{array}{l}\text { 11. Sambaqui Boca da } \\
\text { Barra - WC (Scheel-Ybert } \\
\text { 2000; Scheel-Ybert and } \\
\text { Gaspar 2014) }\end{array}$ & $\begin{array}{l}4050- \\
1280 \mathrm{cal} \\
\mathrm{BP}\end{array}$ & $\begin{array}{l}\text { Trees, shrubs, and palms: Actinostemon sp., Condalia } \\
\text { sp., Cupania sp., aff. Duguetia, Inga } \text { spp. Pouteria sp., } \\
\text { Zollernia sp., Annonaceae, Arecaceae, Myrtaceae }\end{array}$ \\
\hline $\begin{array}{l}\text { 12. Sambaqui da Beirada - } \\
\text { WC (Scheel-Ybert, 2000; } \\
\text { Scheel-Ybert \& Gaspar } \\
\text { 2014) }\end{array}$ & $\begin{array}{l}4700- \\
3770 \text { cal } \\
\text { BP }\end{array}$ & $\begin{array}{l}\text { Trees, shrubs, and palms: Byrsonima sp., Condalia } \\
\text { sp., Cupania sp., aff. Duguetia, Inga sp., Pouteria sp., } \\
\text { Arecaceae, Fabaceae, Myrtaceae }\end{array}$ \\
\hline $\begin{array}{l}\text { 13. Sambaqui da } \\
\text { Pontinha - WC (Scheel- } \\
\text { Ybert 2000; Scheel-Ybert } \\
\text { and Gaspar 2014) }\end{array}$ & $\begin{array}{l}2250- \\
1630 \mathrm{cal} \\
\text { BP }\end{array}$ & $\begin{array}{l}\text { Trees, shrubs, and palms: Actinostemon sp., } \\
\text { Byrsonima sp., Condalia sp., Cupania sp., aff. } \\
\text { Duguetia, Pouteria sp., cf. Swartzia sp., Zollernia sp., } \\
\text { Annonaceae, Arecaceae, Fabaceae, Myrtaceae }\end{array}$ \\
\hline $\begin{array}{l}\text { 14. Sambaqui do Meio - } \\
\text { WC (Scheel-Ybert 2000; } \\
\text { Scheel-Ybert and Gaspar } \\
\text { 2014) }\end{array}$ & $\begin{array}{l}5500 \mathrm{cal} \\
\mathrm{BP}\end{array}$ & $\begin{array}{l}\text { Trees, shrubs, and palms: Araucaria angustifolia, } \\
\text { Actinostemon sp., Cupania sp., aff. Duguetia, Zollernia } \\
\text { sp., Inga sp., Pouteria sp., Fabaceae, Myrtaceae }\end{array}$ \\
\hline $\begin{array}{l}\text { 15. Sambaqui do Forte - } \\
\text { WC (Scheel-Ybert 2000; } \\
\text { Scheel-Ybert and Gaspar } \\
\text { 2014) }\end{array}$ & $\begin{array}{l}5900- \\
1800 \text { cal } \\
\text { BP }\end{array}$ & $\begin{array}{l}\text { Trees, shrubs, and palms: Actinostemon sp., } \\
\text { Byrsonima sp., Cupania sp., Condalia sp., aff. } \\
\text { Duguetia, Erythroxylum sp., Inga spp., Mouriri sp., } \\
\text { Pouteria sp., cf. Swartzia sp., Zollernia sp., } \\
\text { Annonaceae, Arecaceae, Chrysobalanaceae, Fabaceae, } \\
\text { Myrtaceae }\end{array}$ \\
\hline $\begin{array}{l}\text { 16. Moraes - PH, S } \\
\text { (Boyadjian 2007) }\end{array}$ & $\begin{array}{l}5900- \\
4500 \mathrm{BP}\end{array}$ & Herbs: Ipomoea batatas, Dioscorea sp. \\
\hline $\begin{array}{l}\text { 18. Enseada I - PH, S } \\
\text { (Wesolowski et al. 2007; } \\
\text { Wesolowski et al. 2010) }\end{array}$ & $\begin{array}{l}\text { ca. } 1390 \\
\text { BP }\end{array}$ & $\begin{array}{l}\text { Herbs: Ipomoea batatas, Zea mays, Poaceae } \\
\text { Trees, shrubs, and palms: Araucaria angustifolia }\end{array}$ \\
\hline $\begin{array}{l}\text { 19. Forte Marechal Luz- } \\
\text { PH, S (Wesolowski et al. } \\
\text { 2007; Wesolowski et al. } \\
\text { 2010) }\end{array}$ & $\begin{array}{l}\text { ca. } \\
1110-850 \\
\text { BP }\end{array}$ & $\begin{array}{l}\text { Herbs: Ipomoea batatas, Poaceae } \\
\text { Trees, shrubs, and palms: Araucaria angustifolia }\end{array}$ \\
\hline $\begin{array}{l}\text { 20. Morro do Ouro - PH, S } \\
\text { (Wesolowski et al. 2007; } \\
\text { Wesolowski et al. 2010) }\end{array}$ & $\begin{array}{l}\text { ca. } 4030 \\
\text { BP }\end{array}$ & Herbs: Ipomoea batatas, Dioscorea sp., Poaceae \\
\hline $\begin{array}{l}\text { 21. Itacoara - PH, S } \\
\text { (Wesolowski et al. 2007; } \\
\text { Wesolowski et al. 2010) }\end{array}$ & $\begin{array}{l}\text { ca. } 550 \\
\text { BP }\end{array}$ & $\begin{array}{l}\text { Herbs: Ipomoea batatas, Zea mays, Poaceae } \\
\text { Trees, shrubs, and palms: Araucaria angustifolia, } \\
\text { Arecaceae }\end{array}$ \\
\hline
\end{tabular}


Table 1 (continued)

\begin{tabular}{|c|c|c|}
\hline $\begin{array}{l}\text { Archaeological site - type } \\
\text { of remain (reference) }\end{array}$ & Date & Plants \\
\hline $\begin{array}{l}\text { 22. Jabuticabeira II - PH, } \\
\text { S, WC (Boyadjian 2007; } \\
\text { Boyadjian 2012; Scheel- } \\
\text { Ybert and Gaspar 2014; } \\
\text { Boyadjian et al. 2016) }\end{array}$ & $\begin{array}{l}2950- \\
1700 \text { cal } \\
\text { BP }\end{array}$ & $\begin{array}{l}\text { Herbs: Ipomoea batatas, Zea mays, Calathea sp., } \\
\text { Dioscorea sp., Poaceae } \\
\text { Trees, shrubs, and palms: cf. Eugenia uniflora L., } \\
\text { Colubrina sp., Cupania sp., Ficus sp., Mouriri sp., } \\
\text { Pouteria sp., Anacardiaceae, Annonaceae, Arecaceae, } \\
\text { Chrysobalanaceae, Euphorbiaceae Juss., Fabaceae, } \\
\text { Myrtaceae, Rubiaceae }\end{array}$ \\
\hline $\begin{array}{l}\text { 23.Tucumã - PH (Hilbert } \\
\text { 2017) }\end{array}$ & $\begin{array}{l}\text { ca. } \\
1650 \text { cal } \\
\text { BP }\end{array}$ & $\begin{array}{l}\text { Herbs: Cucurbita sp., Oryza sp., Asteraceae, } \\
\text { Marantaceae R.Brown, Poaceae } \\
\text { Trees, shrubs, and palms: Celtis sp., Annonaceae, } \\
\text { Arecaceae }\end{array}$ \\
\hline $\begin{array}{l}\text { 23.Tucumã - PH (Hilbert } \\
\text { 2017) }\end{array}$ & $\begin{array}{l}4300- \\
1650 \text { cal } \\
\text { BP }\end{array}$ & $\begin{array}{l}\text { Herbs: Cucurbita sp., Oryza sp., Zea mays, } \\
\text { Asteraceae, Marantaceae, Poaceae } \\
\text { Trees, shrubs, and palms: Celtis sp., Annonaceae, } \\
\text { Arecaceae }\end{array}$ \\
\hline $\begin{array}{l}\text { 24. Monte Castelo PH, } \\
\text { NWC (Furquim et al. } \\
\text { 2021; Hilbert 2017; Hilbert } \\
\text { et al. 2017) }\end{array}$ & $\begin{array}{l}6000- \\
700 \text { cal } \\
\text { BP }\end{array}$ & $\begin{array}{l}\text { Herbs: Cucurbita sp., Oryza sp., Zea mays, } \\
\text { Asteraceae, Marantaceae, Poaceae } \\
\text { Trees, shrubs, and palms: Bertholletia excelsa, } \\
\text { Mauritia flexuosa, Astrocaryum sp., Byrsonima sp., } \\
\text { Celtis sp., Theobroma sp., Annonaceae, Arecaceae }\end{array}$ \\
\hline $\begin{array}{l}\text { 25. Isla del Tesoro - PH } \\
\text { (Lombardo et al. 2020) }\end{array}$ & $\begin{array}{l}8800- \\
4100 \text { cal } \\
\text { BP }\end{array}$ & $\begin{array}{l}\text { Herbs: Zea mays, c.f. Calathea sp., Cucurbita sp., } \\
\text { Heliconia sp., Manihot sp., Oryza sp., Bambusoideae, } \\
\text { Cyperaceae, Marantaceae } \\
\text { Trees, shrubs, and palms: Celtis sp., Arecoideae }\end{array}$ \\
\hline $\begin{array}{l}\text { 26. Isla Manechi - PH } \\
\text { (Lombardo et al. 2020) }\end{array}$ & $\begin{array}{l}13,900- \\
5000 \text { cal } \\
\text { BP }\end{array}$ & $\begin{array}{l}\text { Herbs: Zea mays, Cucurbita sp., c.f. Calathea sp., } \\
\text { Heliconia sp., Manihot sp., Oryza sp., Bambusoideae, } \\
\text { Cyperaceae, Marantaceae } \\
\text { Trees, shrubs, and palms: Arecoideae }\end{array}$ \\
\hline $\begin{array}{l}\text { 27, 28. Teotônio and Santa } \\
\text { Paula - PH, S (Watling } \\
\text { et al. 2020) }\end{array}$ & $\begin{array}{l}3000- \\
400 \text { cal } \\
\text { BP }\end{array}$ & $\begin{array}{l}\text { Herbs: Calathea } \text { cf. allouia, Cucurbita } \text { cf. moschata, } \\
\text { Ipomoea batatas, Maranta arundinacea, Zea mays, } \\
\text { Dioscorea } \text { sp. } \\
\text { Trees, shrubs, and palms: Bactris/Astrocaryum sp., } \\
\text { Euterpeae/Attaleinae, Mauritinae/Euterpe sp., } \\
\text { Fabaceae }\end{array}$ \\
\hline $\begin{array}{l}\text { 27. Teotônio - PH, NWC, } \\
\text { S (Watling et al. 2018) }\end{array}$ & $\begin{array}{l}9000- \\
5000 \text { cal. } \\
\text { BP }\end{array}$ & $\begin{array}{l}\text { Herbs: Manihot esculenta, Calathea sp., Cucurbita } \\
\text { sp., Heliconia sp., Phaseolus sp., Strelitziaceae } \\
\text { Trees, shrubs, and palms: Bertholletia excelsa, } \\
\text { Attalea } \text { sp., Bactris/Astrocaryum sp., Euterpel } \\
\text { Oenocarpus sp., Caryocar sp., Ficus sp., Psidium sp., } \\
\text { Arecaceae }\end{array}$ \\
\hline $\begin{array}{l}\text { 29. Serra do Maguari-1 - } \\
\text { PH, S (Maezumi et al. } \\
\text { 2018) }\end{array}$ & $\begin{array}{l}\text { ca. } \\
490 \text { cal } \\
\text { BP }\end{array}$ & $\begin{array}{l}\text { Herbs: Zea mays, Chusquea sp., Cucurbita sp., Pharus } \\
\text { sp., Olyreae } \\
\text { Trees, shrubs, and palms: Astrocaryum sp., Attalea } \\
\text { sp., Arecaceae }\end{array}$ \\
\hline
\end{tabular}


Table 1 (continued)

\begin{tabular}{|c|c|c|}
\hline $\begin{array}{l}\text { Archaeological site - type } \\
\text { of remain (reference) }\end{array}$ & Date & Plants \\
\hline $\begin{array}{l}\text { 30. Lake Caranã - PO } \\
\text { (Maezumi et al. 2018) }\end{array}$ & $\begin{array}{l}4500 \text { cal } \\
\text { BP - } \\
\text { modern }\end{array}$ & $\begin{array}{l}\text { Herbs: Ipomoea batatas, Manihot esculenta, Zea } \\
\text { mays, Cucurbita sp., Solanum sp. } \\
\text { Trees, shrubs, and palms: Acrocomia sp., Aniba sp., } \\
\text { Annona } \text { sp., Astrocaryum sp., Attalea sp., Bactris sp., } \\
\text { Brosimum sp., Byrsonima sp., Caryocar sp., Cecropia } \\
\text { sp., Celtis sp., Eschweilera sp., Hymenaea sp., } \\
\text { Jacaratia } \text { sp., Licania } \text { sp., Mauritia } \text { sp., Mauritiella sp., } \\
\text { Oenocarpus sp., Pouteria sp., Protium sp., Spondias } \\
\text { sp., Tapirira sp., Tetragastris sp., Theobroma sp. }\end{array}$ \\
\hline $\begin{array}{l}\text { 31. Cedro - PH (Troufflard } \\
\text { and Alves 2019) }\end{array}$ & $\begin{array}{l}700- \\
200 \text { cal } \\
\text { BP }\end{array}$ & $\begin{array}{l}\text { Herbs: cf. Maranta arundinacea L., Zea mays, cf. } \\
\text { Calathea sp., Cucurbita sp., Oryza sp. } \\
\text { Trees, shrubs, and palms: Celtis sp., Attaleinae, } \\
\text { Bactris/Astrocaryum sp., Mauritinae/Euterpeae, } \\
\text { Annonaceae }\end{array}$ \\
\hline $\begin{array}{l}\text { 32. Hatahara - PH } \\
\text { (Bozarth et al. 2009) }\end{array}$ & $\begin{array}{l}\text { ca. } \\
1000 \text { cal } \\
\text { BP }\end{array}$ & $\begin{array}{l}\text { Herbs: Zea mays, Calathea sp., Cucurbita sp., } \\
\text { Heliconia sp., Lagenaria sp., Cyperaceae Juss., } \\
\text { Marantaceae } \\
\text { Trees, shrubs, and palms: Bactris sp. }\end{array}$ \\
\hline $\begin{array}{l}\text { 32. Hatahara - PH, S,WC } \\
\text { (Caromano et al. 2013; } \\
\text { Scheel-Ybert et al. 2016; } \\
\text { Cascon 2010) }\end{array}$ & $\begin{array}{l}\text { ca. } \\
1000 \mathrm{cal} \\
\text { BP }\end{array}$ & $\begin{array}{l}\text { Herbs: Zea mays, Cyperus sp., Dioscorea sp., } \\
\text { Cyperaceae } \\
\text { Trees, shrubs, and palms: cf. Attalea maripa (Aubl.) } \\
\text { Mart., cf. Euterpe oleracea Mart., cf. Mauritia } \\
\text { flexuosa; cf. Oenocarpus bataua; Bactris sp., } \\
\text { Byrsonima sp., Cupania sp., Diospyros sp., Genipa sp., } \\
\text { Himathantus sp., Spondias sp., Tapirira sp., Vantanea } \\
\text { sp., Vernonia sp., Anacardiaceae, Annonaceae, } \\
\text { Arecaceae, Chrysobalanaceae, Euphorbiaceae, } \\
\text { Fabaceae, Lecythidaceae A.Rich., Melastomataceae, } \\
\text { Myrtaceae, Rubiaceae, Sapindaceae Juss., Sapotaceae }\end{array}$ \\
\hline $\begin{array}{l}\text { 33, 34, 35. Açutuba, Lago } \\
\text { Grande, Osvaldo - NWC } \\
\text { (da Silva et al. 2016) }\end{array}$ & $\begin{array}{l}1750- \\
750 \text { cal } \\
\text { BP }\end{array}$ & $\begin{array}{l}\text { Herbs: Zea mays, tubers } \\
\text { Trees, shrubs, and palms: Arecaceae }\end{array}$ \\
\hline $\begin{array}{l}\text { 36, } 37,38,39 . \text { Vila Nova I, } \\
\text { Vila Nova II, Floresta, } \\
\text { Lago das Pombas - NWC } \\
\text { (Shock et al. 2014) }\end{array}$ & $\begin{array}{l}2350- \\
450 \text { cal } \\
\text { BP }\end{array}$ & $\begin{array}{l}\text { Trees, shrubs, and palms: Bertholletia excelsa (other } \\
\text { taxa were identified but data are not published) }\end{array}$ \\
\hline $\begin{array}{l}\text { 40. Caldeirão - PH, S } \\
\text { (unpublished data) }\end{array}$ & $\begin{array}{l}\text { ca. } \\
1300-900 \\
\text { BP }\end{array}$ & $\begin{array}{l}\text { Herbs: Canna indica L., Manihot esculenta, Zea mays, } \\
\text { Poaceae } \\
\text { Trees, shrubs, and palms: Bactris gasipaes, } \\
\text { Arecaceae }\end{array}$ \\
\hline $\begin{array}{l}\text { 41. São João - NWC } \\
\text { (Cassino, 2018) }\end{array}$ & $\begin{array}{l}1100-500 \\
\text { BP }\end{array}$ & $\begin{array}{l}\text { Herbs: Zea mays, Solanaceae } \\
\text { Trees, shrubs and palms: Bertholletia excelsa, } \\
\text { Spondias mombin, Astrocaryum sp., Byrsonima sp., } \\
\text { Caryocar sp., Oenocarpus sp., Theobroma sp., } \\
\text { Annonaceae, Arecaceae, Fabaceae }\end{array}$ \\
\hline
\end{tabular}


Table 1 (continued)

\begin{tabular}{|c|c|c|}
\hline $\begin{array}{l}\text { Archaeological site - type } \\
\text { of remain (reference) }\end{array}$ & Date & Plants \\
\hline $\begin{array}{l}\text { 42, 46. Cruzeirinho, } \\
\text { Tequinho - D, NWC } \\
\text { (Pärssinen et al. 2020) }\end{array}$ & $\begin{array}{l}2000- \\
1300 \text { cal } \\
\text { BP }\end{array}$ & $\begin{array}{l}\text { Trees, shrubs, and palms: Attalea maripa (Aubl.) } \\
\text { Mart., Attalea phalerata, Bactris concinna Mart., } \\
\text { Bactris gasipaes, Bertholletia excelsa, Oenocarpus } \\
\text { mapora H.Karst., Spondias mombin, Astrocaryum sp., } \\
\text { Gustavia sp. }\end{array}$ \\
\hline $\begin{array}{l}\text { 43, 44, 45, 46, 47, 48, 49, } \\
\text { 50. Fazenda Iquiri II, Sol } \\
\text { de Maio, Campo } \\
\text { Esperança, Tequinho, El } \\
\text { Círculo, Las Palmeras, } \\
\text { Chacra Telería, } \\
\text { Tumichuchua - PH } \\
\text { (Watling et al. 2015) }\end{array}$ & $\begin{array}{l}2100-150 \\
\text { BP }\end{array}$ & $\begin{array}{l}\text { Herbs: Zea mays, Cucurbita sp., Heliconia sp., } \\
\text { Chusqueinae, Olyreae, Asteraceae, Marantaceae, } \\
\text { Strelitziaceae Hutch. } \\
\text { Trees, shrubs, and palms: Celtis sp., Annonaceae, } \\
\text { Arecaceae }\end{array}$ \\
\hline $\begin{array}{l}\text { 51. Aterro dos Bichos - } \\
\text { NWC (Roosevelt 1989) }\end{array}$ & $\begin{array}{l}1500-650 \\
\mathrm{BP}\end{array}$ & $\begin{array}{l}\text { Trees, shrubs, and palms: Astrocaryum sp., Euterpe } \\
\text { spp., Inga spp., Sterculia sp. }\end{array}$ \\
\hline $\begin{array}{l}\text { 52. Bonin - PH, S } \\
\text { (Cortelleti et al. 2016) }\end{array}$ & $\begin{array}{l}700- \\
600 \mathrm{cal} \\
\mathrm{BP}\end{array}$ & $\begin{array}{l}\text { Herbs: Manihot esculenta, Zea mays, Cucurbita sp., } \\
\text { cf. Dioscorea sp., Phaseolus sp., Asteraceae, } \\
\text { Marantaceae, Poaceae } \\
\text { Trees, shrubs, and palms: Arecaceae }\end{array}$ \\
\hline
\end{tabular}

\section{References}

Anderson AB, Posey DA, Balée W (1989) Management of a tropical scrub savanna by the Gorotire Kayapó of Brazil. In: Posey DA, Balée W (eds) Resource management in Amazonia: indigenous and folk strategies, Advances in economic botany, vol 7. New York Botanical Garden, Bronx/New York, pp 159-173

Anderson E (2005) Plants, man and life. Courier Dover Publications, Mineola

Angeles Flores R (2015) Uso de recursos vegetais em Lapa Grande de Taquaraçu: evidencias macro e microscópicas. Master's dissertation, Universidade de São Paulo, São Paulo

Angeles Flores R, de Sousa JCM, de Mello Araujo AG, Ceccantini G (2016) Before Lagoa Santa: micro-remain and technological analysis in a lithic artifact from the Itaparica industry. J Lithic Stud 3(1):6-29. https://doi.org/10.2218/jls.v3i1.1423

Arroyo-Kalin M (2017) Human niche construction and population growth in pre-Columbian Amazonia. Arch Inter 20:122-136. https://doi.org/10.5334/ai-367

Atroch AL, Nascimento Filho FJ, Ângelo PC, Freitas DV, Sousa NR, Clement CR (2012) Domestication and breeding of guarana. In: Borém A, Lopes MTG, Clement CR, Noda H (eds) Domestication and breeding: Amazonian species. Editora da Univ. Fed. Viçosa, Viçosa, pp 333-360

Balée W (1989) The culture of Amazonian forests. In: Posey DA, Balée W (eds) Resource management in Amazonia: indigenous and folk strategies, Advances in economic botany, vol 7. The New York Botanical Garden, Bronx/New York, pp 1-21

Balée W (2013) Cultural forests of the Amazon: a historical ecology of people and their landscapes. The University of Alabama Press, Tuscaloosa

Ball T, Chandler-Ezell K, Dickau R, Duncan N, Hart TC, Iriarte J, Lentfer C, Logan A, Lu H, Madella M, Pearsall DM, Piperno D, Rosen AM, Vrydaghs L, Weisskopf A, Zhang J (2015) Phytoliths as a tool for investigations of agricultural origins and dispersals around the world. $\mathrm{J}$ Archaeol Sci 68:32-45. https://doi.org/10.1016/j.jas.2015.08.010 
Bandeira AM (2013) Ocupações humanas pré-coloniais na ilha de São Luís-MA: inserção dos sítios arqueológicos na paisagem, cronologia e cultura material cerâmica. Doctoral thesis, Universidade de São Paulo, São Paulo

Bitencourt ALV, Krauspenhar PM (2006) Possible prehistoric anthropogenic effect on Araucaria angustifolia (Bert.) O. Kuntze expansion during the late Holocene. Rev Bras Paleont 9(1):109-116. https://doi.org/10.4072/rbp.2006.1.12

Blench R (2012) The role of agriculture in explaining the diversity of Amerindian languages. In: Isendahl C (ed) The past ahead. Language, culture and identity in the Neotropics, Studies in global archaeologyl, vol 18. Acta Universitatis Upsaliensis, Uppsala, pp 13-38

Bowser BJ, Zedeño MN (2009) The archaeology of meaningful places. University of Utah Press, Salt Lake City

Boyadjian CHC (2007) Microfósseis contidos no cálculo dentário como evidência do uso de recursos vegetais nos sambaquis de Jabuticabeira II (SC) e Moraes (SP). Master's dissertation, Universidade de São Paulo, São Paulo

Boyadjian CHC (2012) Análise e identificação de microvestígios vegetais de cálculo dentário para a reconstrução de dieta sambaquieira: estudo de caso de Jabuticabeira II, SC. Doctoral thesis, Universidade de São Paulo, São Paulo

Boyadjian CHC, Eggers S, Reinhard KJ, Scheel-Ybert R (2016) Dieta no sambaqui Jabuticabeira-II (SC): consumo de plantas revelado por microvestígios provenientes de cálculo dentário. Cad LEPAARQ 13(25):131-161. https://doi.org/10.15210/lepaarq.v13i25.7395

Bozarth SR, Price KP, Woods W, Neves EG, Rebellato L (2009) Phytoliths and terra preta: the Hatahara site example. In: Woods W, Teixeira WG, Lehmann J, Steiner C, WinklerPrins AM, Rebellato L (eds) Amazonian dark earths: Wim Sombroek's vision. Springer, Heidelberg, pp 85-98

Brown CH, Clement CR, Epps P, Luedeling E, Wichmann S (2013a) The paleobiolinguistics of domesticated chili pepper (Capsicum spp.). Ethnobiol Let 4:1-11. https://doi.org/10.14237/ ebl.4.2013.5

Brown CH, Clement CR, Epps P, Luedeling E, Wichmann S (2013b) The paleobiolinguistics of domesticated manioc (Manihot esculenta). Ethnobiol Let 4:61-70. https://doi.org/10.14237/ ebl.4.2013.2

Brown CH, Clement CR, Epps P, Luedeling E, Wichmann S (2014a) The paleobiolinguistics of maize (Zea mays L.). Ethnobiol Let 5(1):52-64. https://doi.org/10.14237/ebl.5.2014.130

Brown CH, Clement CR, Epps P, Luedeling E, Wichmann S (2014b) The paleobiolinguistics of the common bean (Phaseolus vulgaris L.). Ethnobiol Let 5 (0):104-115. https://doi.org/10.14237/ ebl.5.2014.203

Brugger SO, Gobet E, van Leeuwen JFN, Ledru M-P, Colombaroli D, van der Knaap WO, Lombardo U, Escobar-Torrez K, Finsinger W, Rodrigues L, Giesche A, Zarate M, Veit H, Tinner W (2016) Long-term man-environment interactions in the Bolivian Amazon: 8000 years of vegetation dynamics. Quatern Sci Rev 132:114-128. https://doi.org/10.1016/j.quascirev.2015.11.001

Bruno MC (2019) Indigenous American agricultural contributions to modern global food systems. Oxford Research Encyclopedia of environmental science. Oxford University Press, Oxford. https://doi.org/10.1093/acrefore/9780199389414.013.176

Caromano CF, Cascon LM, Neves EG, Scheel-Ybert R (2013) Revealing fires and rich diets: macro-and micro-archaeobotanical analysis at the Hatahara Site, Central Amazonia. Tipiti 11(2):40-51

Carson JF, Whitney BS, Mayle FE, Iriarte J, Prumers H, Soto JD, Watling J (2014) Environmental impact of geometric earthwork construction in pre-Columbian Amazonia. Proc Natl Acad Sci U S A 111(29):10497-10502. https://doi.org/10.1073/pnas.1321770111

Cascon LM (2010) Alimentação na floresta tropical: um estudo de caso no sítio Hatahara, Amazônia Central, com base em microvestígios botânicos. Master's dissertation, Universidade Federal do Rio de Janeiro, Rio de Janeiro

Cassino MF (2018) Manejo e uso de recursos florísticos em períodos pré-coloniais na Amazônia: um estudo de caso na RDS Amanã. Instituto de Desenvolvimento Sustentável Mamirauá, Tefé 
Cassino MF, Alves RP, Levis C, Watling J, Junqueira AB, Shock MP, Ferreira MJ, Andrade VLC, Furquim LP, Coelho SD, Tamanaha EK, Neves EG, Clement CR (2019) Ethnobotany and ethnoecology applied to historical ecology. In: Albuquerque UP, Lucena RFP, Cunha LVFC, Alves RRN (eds) Methods and techniques in ethnobiology and ethnoecology. Springer, New York, pp 187-208. https://doi.org/10.1007/978-1-4939-8919-5_13

Chaves SAdM (2005) Novas perspectivas paleoetnobotânicas e paleovegetacionais do Planalto Central do Brasil: uma proposta palinológica. In: Vialou ÁV (ed) Pré-história do Mato Grosso, vol 1. Santa Elina. EDUSP, São Paulo, pp 149-154

Chiou KL, Hastorf CA (2014) A systematic approach to species-level identification of chile pepper (Capsicum spp.) seeds: establishing the groundwork for tracking the domestication and movement of chile peppers through the Americas and beyond. Econ Bot 68(3):316-336. https://doi.org/10.1007/s12231-014-9279-2

Clement CR (1999) 1492 and the loss of Amazonian crop genetic resources. I. The relation between domestication and human population decline. Econ Bot 53(2):188-202. https://doi. org/10.1007/BF02866498

Clement CR (2019) Domesticação da floresta \& subdesenvolvimento da Amazônia. In: Mendes dos Santos G (ed) Grupo de Estudos Estratégicos Amazônicos, Caderno de Debates, Tomo XIV. Instituto Nacional de Pesquisas da Amazônia, Manaus, pp 11-52

Clement CR, Cassino MF (2018) Landscape domestication and archaeology. In: Smith C (ed) Encyclopedia of global archaeology. Springer, New York, pp 1-8. https://doi. org/10.1007/978-3-319-51726-1_817-2

Clement CR, Cristo-Araújo M, Coppens d'Eeckenbrugge G, Alves Pereira A, Picanço-Rodrigues D (2010) Origin and domestication of native Amazonian crops. Diversity 2(1):72-106. https:// doi.org/10.3390/d2010072

Clement CR, Picanço Rodrigues D, Alves Pereira A, Mühlen GS, Cristo Araújo M, Moreira PA, Lins J, Reis VM (2016) Crop domestication in the upper Madeira River basin. Bol Mus Para Emílio Goeldi Cien Hum 11(1):193-205. https://doi.org/10.1590/1981.81222016000100010

Colonese AC, Collins M, Lucquin A, Eustace M, Hancock Y, Ponzoni RAR, Mora A, Smith C, DeBlasis P, Figuti L (2014) Long-term resilience of late Holocene coastal subsistence system in southeastern South America. PLoS One 9(4):e93854. https://doi.org/10.1371/journal. pone.0093854

Corteletti R, Dickau R, DeBlasis P, Iriarte J (2016) Analises de grãos de amido e fitólitos nas terras altas do sul do Brasil: repensando a economia e mobilidade dos grupos proto-Jê meridionais. Cad LEPAARQ 13(25):162-196. https://doi.org/10.15210/lepaarq.v13i25.7369

Crosby AW (2003) The Columbian exchange: biological and cultural consequences of 1492, 30th Anniversary edn. Greenwood Publishing Group, West Port

Denevan WM (1992) Native American populations in 1492: recent research and a revised hemispheric estimate. In: Denevan WM (ed) The native population of the Americas in 1492, 2nd edn. Univ. of Wisconsin Press, Madison, pp xvii-xxix

Denevan WM (2001) Cultivated landscapes of native Amazonia and the Andes. Oxford geographical and environmental studies. Oxford University Press, Oxford

Donini CVZDS, Fiori MM, dos Santos CFM (2017) Flores e cascas: exploração de cravo, Dicypellium caryophyllaceum e Syzygium aromaticum, no século XVIII. Paper presented at the VIII Congresso Internacional de História, Maringá, Paraná,

Eggers S, Parks M, Grupe G, Reinhard KJ (2011) Paleoamerican diet, migration and morphology in Brazil: archaeological complexity of the earliest Americans. PLoS One 6(9):e23962. https:// doi.org/10.1371/journal.pone.0023962

Erickson CL (2003) Historical ecology and future explorations. In: Lehmann J, Kern DC, Glaser B, Woods WI (eds) Amazonian Dark Earths: origin, properties, management. Kluwer, Dordrecht, pp 455-500

Figuti L, Plens CR, DeBlasis P (2013) Small sambaquis and big chronologies: shellmound building and hunter-gatherers in Neotropical highlands. Radiocarbon 55(2-3):1215-1221. https:// doi.org/10.1017/S0033822200048128 
FUNAI (2020) Fundação Nacional do Índio. http://www.funai.gov.br/index.php/shape. Accessed July 2020

Furquim LP, Watling J, Hilbert LM, Shock MP, Prestes-Carneiro G, Calo CM, Py-Daniel AR, Brandão K, Pugliese F, Zimpel CA, Silva CA, Neves EG (2021) Facing Change through Diversity: Resilience and Diversification of Plant Management Strategies during the Mid to Late Holocene Transition at the Monte Castelo Shellmound, SW Amazonia. Quaternary 4:8. https://doi.org/10.3390/quat4010008

Gaspar MD, DeBlasis P, Fish SK, Fish PR (2008) Sambaqui (shell mound) societies of coastal Brazil. In: Silverman H, Isbell WH (eds) The handbook of South American archaeology. Springer, pp 319-335. https://doi.org/10.1007/978-0-387-74907-5_18

Graff SR (2018) Archaeological studies of cooking and food preparation. J Arch Res 26(3):305-351. https://doi.org/10.1007/s10814-017-9111-5

Grobman A, Bonavia D, Dillehay TD, Piperno DR, Iriarte J, Holst I (2012) Preceramic maize from Paredones and Huaca Prieta, Peru. Proc Natl Acad Sci U S A 109(5):1755-1759. https://doi. org/10.1073/pnas.1120270109

Hastorf C (1998) The cultural life of early domestic plant use. Antiquity 72(278):773-782. https:// doi.org/10.1017/S0003598X00087366

Hastorf CA (1999) Recent research in paleoethnobotany. J Arch Res 7(1):55-103

Heckenberger MJ (1998) Manioc agriculture and sedentism in Amazonia: the Upper Xingu example. Antiquity $72(277): 633-648$

Hemming J (1995) Red gold: the conquest of the Brazilian Indians, 2nd edn. Papermac, London

Henderson JS, Joyce RA, Hall GR, Hurst WJ, McGovern PE (2007) Chemical and archaeological evidence for the earliest cacao beverages. Proc Natl Acad Sci U S A 104(48):18937-18940. https://doi.org/10.1073/pnas.0708815104

Henry AG, Hudson HF, Piperno DR (2009) Changes in starch grain morphologies from cooking. J Arch Sci 36(3):915-922. https://doi.org/10.1016/j.jas.2008.11.008

Hilbert L, Neves EG, Pugliese F, Whitney BS, Shock M, Veasey E, Zimpel CA, Iriarte J (2017) Evidence for mid-Holocene rice domestication in the Americas. Nat Ecol Evol 1(11):1693-1698. https://doi.org/10.1038/s41559-017-0322-4

Hilbert LM (2017) Investigating plant management in the Monte Castelo (Rondônia-Brazil) and Tucumã (Pará-Brazil) shell mounds using phytolith analysis. PhD Thesis, University of Exeter, Exeter

Imazio da Silveira M, Schaan DP (2005) Onde a Amazônia encontra o mar: estudando os sambaquis do Pará. Rev Arque 18(1):67-79. https://doi.org/10.24885/sab.v18i1.205

Ingold T (1993) The temporality of the landscape. World Arch 25(2):152-174

Iriarte J, Behling H (2007) The expansion of Araucaria forest in the southern Brazilian highlands during the last 4000 years and its implications for the development of the Taquara/Itararé tradition. Environ Arch 12(2):115-127. https://doi.org/10.1179/174963107x226390

Iriarte J, Gillam JC, Marozzi O (2008) Monumental burials and memorial feasting: an example from the southern Brazilian highlands. Antiquity 82(318):947-961. https://doi.org/10.1017/ S0003598X00097702

ISA (2020) Povos indígenas no Brasil - Línguas. Instituto Socioambiental. https://pib.socioambiental.org/pt/L\%C3\%ADnguas. Accessed July 2020

Kistler L, Maezumi SY, De Souza JG, Przelomska NA, Costa FM, Smith O, Loiselle H, RamosMadrigal J, Wales N, Ribeiro ER (2018) Multiproxy evidence highlights a complex evolutionary legacy of maize in South America. Science 362(6420):1309-1313. https://doi.org/10.1126/ science.aav0207

Klokler DM (2012) Consumo ritual, consumo no ritual: festins funerários e sambaquis. Rev Habitus 10(1):83-104. https://doi.org/10.18224/hab.v10.1.2012.83-104

Koch A, Brierley C, Maslin MM, Lewis SL (2019) Earth system impacts of the European arrival and Great Dying in the Americas after 1492. Quatern Sci Rev 207:13-36. https://doi. org/10.1016/j.quascirev.2018.12.004 
Lahaye C, Guérin G, Boëda E, Fontugne M, Hatté C, Frouin M, Clemente-Conted I, Pino M, Felice GD, Guidon N, Lourdeau A, Pagli M, Pessis AM, Da Costa A (2015) New insights into a late-Pleistocene human occupation in America: the Vale da Pedra Furada complete chronological study. Quat Geochronol 30:445-451. https://doi.org/10.1016/j.quageo.2015.03.009

Lathrap DW (1977) Our father the cayman, our mother the gourd: Spinden revisited, or a unitary model for emergence of agriculture in the New World. In: Reed CA (ed) Origins of agriculture. Mouton, The Hague, pp 713-754

Lebot V (2009) Tropical root and tuber crops: Cassava, sweet potato, yams and aroids. CAB International, Oxford, UK

Lee-Thorp JA (2008) On isotopes and old bones. Archaeometry 50(6):925-950. https://doi. org/10.1111/j.1475-4754.2008.00441.x

Levis C, Costa FRC, Bongers F, Peña-Claros M, Clement CR, Junqueira AB, Neves EG, Tamanaha EK, Figueiredo FOG, Salomão RP, Castilho CV, Magnusson WE, Phillips OL, Guevara JE, Sabatier D, Molino J-F, López DC, Mendoza AM, Pitman NCA, Duque A, Vargas PN, Zartman CE, Vasquez R, Andrade A, Camargo JL, Feldpausch TR, Laurance SGW, Laurance WF, Killeen TJ, Nascimento HEM, Montero JC, Mostacedo B, Amaral IL, Guimaraes Vieira IC, Brienen R, Castellanos H, Terborgh J, Vargas Carim MJ, Guimarães JRS, Coelho LS, Matos FDDA, Wittmann F, Mogollón HF, Damasco G, Dávila N, García-Villacorta R, Honorio Coronado EN, Emilio T, DdA LF, Schietti J, Souza P, Targhetta N, Comiskey JA, Marimon BS, Marimon B-H Jr, Neill D, Alonso A, Arroyo L, Carvalho FA, Souza FC, Dallmeier F, Pansonato MP, Duivenvoorden JF, PVA F, Stevenson Diaz PR, Araujo-Murakami A, Aymard CGA, Baraloto C, Amaral DD, Engel J, Henkel TW, Maas P, Petronelli P, JDC R, Stropp J, Daly D, Gribel R, Paredes MR, Silveira M, Thomas-Caesar R, Baker TR, Silva NF, Ferreira LV, Peres CA, Silman MR, Cerón C, Valverde FC, Di Fiore A, Jimenez EM, Peñuela Mora MC, Toledo M, Barbosa EM, Bonates LCM, Arboleda NC, Farias ES, Fuentes A, Guillaumet J-L, Jorgensen PM, Malhi Y, IPA M, Phillips JF, Prieto A, Rudas A, Ruschell AR, Silva N, von Hildebrand P, Vos VA, Zent EL, Zent S, Cintra BBL, Nascimento MT, Oliveira AA, Ramirez-Angulo H, Ramos JF, Rivas-Torres G, Schöngart J, Sierra R, Tirado M, van der Heijden G, Torre EV, Wang O, Young KR, Baider C, Cano A, Farfan-Rios W, Ferreira C, Hoffman B, Mendoza C, Mesones I, Torres-Lezama A, MNU M, van Andel TR, Villarroel D, Zagt R, Alexiades MN, Balslev H, Garcia-Cabrera K, Gonzales T, Hernandez L, Huamantupa-Chuquimaco I, Manzatto AG, Milliken W, Palacios Cuenca W, Pansini S, Pauletto D, Ramirez Arevalo F, Costa Reis NF, Sampaio AF, Urrego Giraldo LE, Sandoval EHV, Gamarra LV, Vela CIA, ter Steege H (2017) Persistent effects of pre-Columbian plant domestication on Amazonian forest composition. Science 355(6328):925-931. https://doi.org/10.1126/science.aal0157

Levis C, Flores BM, Moreira PA, Luize BG, Alves RP, Franco-Moraes J, Lins J, Konings E, PeñaClaros M, Bongers F, Costa FRC, Clement CR (2018) How people domesticated Amazonian forests. Front Ecol Evol 5:171. https://doi.org/10.3389/fevo.2017.00171

Lombardo U, Iriarte J, Hilbert L, Ruiz-Pérez J, Capriles JM, Veit H (2020) Early Holocene crop cultivation and landscape modification in Amazonia. Nature 581(7807):190-193. https://doi. org/10.1038/s41586-020-2162-7

Lombardo U, Szabo K, Capriles JM, May J-H, Amelung W, Hutterer R, Lehndorff E, Plotzki A, Veit H (2013) Early and middle holocene hunter-gatherer occupations in western Amazonia: the hidden shell middens. PLoS One 8(8):e72746. https://doi.org/10.1371/journal.pone.0072746

Loukotka Č (1967) Annals map supplement number eight ethno-linguistic distribution of South American Indians. Ann Am Assoc Geogr 57(2):437-438. https://doi.org/10.1111/j.14678306.1967.tb00614.x

Machado JS (2012) Lugares de gente: mulheres, plantas e redes de troca no delta amazônico. Doctoral thesis, Museu Nacional, Universidade Federal de Rio de Janeiro, Rio de Janeiro

Machado JS (2016) Caminhos e paradas. Perspectivas sobre o território Laklãnõ (Xokleng). Rev Mus Arqueo Etnol (27):179-196. https://doi.org/10.11606/issn.2448-1750.revmae.2016.137298 
Maezumi SY, Alves D, Robinson M, Souza JG, Levis C, Barnett RL, Almeida de Oliveira E, Urrego D, Schaan D, Iriarte J (2018) The legacy of 4,500 years of polyculture agroforestry in the eastern Amazon. Nat Plants 4(8):540-547. https://doi.org/10.1038/s41477-018-0205-y

Medina JT (ed) (1934) The discovery of the Amazon according to the account of Friar Gaspar de Carvajal and other documents (trans: Heaton HC, Lee BT). The American Geographical Society, New York

Métraux A (1946) The Caingang. In: Steward JH (ed) Handbook of South American Indians, The marginal tribes, vol 1. Smithsonian Institution, Washington, pp 445-477

Neves EG, Petersen JB (2006) The political economy of pre-columbian Amerindians: landscape transformations in Central Amazonia. In: Balée WL, Erickson CL (eds) Time and complexity in historical ecology: studies in the Neotropical lowlands. Columbia University Press, New York, pp 279-310

Noelli FS (1999) A ocupação humana na região sul do Brasil: arqueologia, debates e perspectivas-1872-2000. Revista USP (44):218-269. https://doi.org/10.11606/issn.2316-9036. v0i44p218-269

Olsen KM, Schaal BA (1999) Evidence on the origin of Cassava: Phylogeography of Manihot esculenta. Proc Natl Acad Sci U S A 96:5586-5591

Ortega DD (2019) Microvestígios botânicos em artefatos líticos do sítio Lapa do Santo (Lagoa Santa, Minas Gerais). Master's dissertation, Universidade de São Paulo, São Paulo

Pärssinen M, Ferreira E, Virtanen PK, Ranzi A (2020) Domestication in motion: macrofossils of pre-colonial Brazilian nuts, palms and other Amazonian planted tree species found in the Upper Purus. Environ Arch 25:1-14. https://doi.org/10.1080/14614103.2020.1765295

Pearsall DM (1992) The origins of plant cultivation in South America. In: Cowan CW, Watson PJ (eds) The origins of agriculture: an international perspective. Smithsonian Institution Press, Washington, DC, pp 173-206

Pearsall DM (2015) Paleoethnobotany: a handbook of procedures, 3rd edn. Left Coast Press, Walnut Creek

Pezo-Lanfranco L, Eggers S, Petronilho C, Toso A, da Rocha BD, Von Tersch M, dos Santos AMP, Ramos da Costa B, Meyer R, Colonese AC (2018) Middle Holocene plant cultivation on the Atlantic Forest coast of Brazil? R Soc Open Sci 5(9):180432. https://doi.org/10.1098/ rsos. 180432

Piperno DR (2006) Phytoliths: a comprehensive guide for archaeologists and paleoecologists. AltaMira Press, Lanham

Piperno DR, Clary KH, Cooke RG, Ranere AJ, Weiland D (1985) Preceramic maize in central Panama: phytolith and pollen evidence. Amer Anthro 87(4):871-878. https://doi.org/10.1525/ aa.1985.87.4.02a00090

Piperno DR, Dillehay TD (2008) Starch grains on human teeth reveal early broad crop diet in northern Peru. Proc Natl Acad Sci U S A 105(50):19622-19627. https://doi.org/10.1073/ pnas.0808752105

Piperno DR, Holst I (1998) The presence of starch grains on prehistoric stone tools from the humid Neotropics: indications of early tuber use and agriculture in Panama. J Arch Sci 25(8):765-776. https://doi.org/10.1006/jasc.1997.0258

Piperno DR, Ranere AJ, Holst I, Iriarte J, Dickau R (2009) Starch grain and phytolith evidence for early ninth millennium BP maize from the Central Balsas River Valley, Mexico. Proc Natl Acad Sci U S A 106(13):5019-5024. https://doi.org/10.1073/pnas.0812525106

Piperno DR, Stothert KE (2003) Phytolith evidence for early Holocene Cucurbita domestication in Southwest Ecuador. Science 299(5609):1054-1057. https://doi.org/10.1126/science.1080365

Politis GG (1996) Moving to produce: Nukak mobility and settlement patterns in Amazonia. World Arch 27(3):492-511. https://doi.org/10.1080/00438243.1996.9980322

Posey DA (1985) Indigenous management of tropical forest ecosystems: the case of the Kayapo Indians of the Brazilian Amazon. Agrofor Syst 3(2):139-158. https://doi.org/10.1007/ BF00122640 
Pugliese FA, Zimpel Neto CA, Neves EG (2018) What do Amazonian shellmounds tell us about the long-term indigenous history of South America? Encyclopedia of global archaeology. Springer, Cham. https://doi.org/10.1007/978-3-319-51726-1_3030-2

Purugganan MD, Fuller DQ (2011) Archaeological data reveal slow rates of evolution during plant domestication. Evolution 65(1):171-183. https://doi.org/10.1111/j.1558-5646.2010.01093.x

Reis MS, Ladio A, Peroni N (2014) Landscapes with Araucaria in South America: evidence for a cultural dimension. Ecol Soc 19(2):4. https://doi.org/10.5751/ES-06163-190243

Renfrew C, Bellwood P (2002) Examining the farming/language dispersal hypothesis. McDonald Institute for Archaeological Research, Cambridge

Resende ET, Prous A (1991) Os vestígios vegetais do Grande Abrigo de Santana do Riacho. Arq Mus Hist Nat UFMG 12:87-111

Roosevelt AC (1989) Resource management in Amazonia before the conquest: beyond ethnographic projection. In: Posey DA, Balée W (eds) Resource management in Amazonia: indigenous and folk strategies, Advances in economic botany, vol 7. Bronx/New York, The New York Botanical Garden, pp 30-62

Roosevelt AC (1998) Ancient and modern hunter-gatherers of lowland South America: an evolutionary problem. In: Balée W (ed) Advances in historical ecology. Columbia University Press, New York, pp 190-212

Roosevelt AC (2000) The lower Amazon: a dynamic human habitat. In: Lentz DL (ed) Imperfect balance: landscape transformations in the precolumbian Americas. Columbia University Press, New York, pp 455-479

Roosevelt AC, Lima da Costa M, Lopes Machado C, Michab M, Mercier N, Valladas H, Feathers J, Barnett W, Imazio da Silveira M, Henderson A, Sliva J, Chernoff B, Reese DS, Holman JA, Toth N, Shick K (1996) Paleoindian cave dwellers in the Amazon: the peopling of the Americas. Science 272(5260):373-384. https://doi.org/10.1126/science.272.5260.373

Rull V, Montoya E (2014) Mauritia flexuosa palm swamp communities: natural or human-made? A palynological study of the Gran Sabana region (northern South America) within a neotropical context. Quatern Sci Rev 99:17-33. https://doi.org/10.1016/j.quascirev.2014.06.007

Santos IT (2014) Alimentação de grupos humanos pré-históricos do sítio arqueológico Furna do Estrago, Pernambuco, Brasil. Doctoral thesis, Fundação Oswaldo Cruz, Rio de Janeiro

Scheel-Ybert R (2000) Vegetation stability in the Southeastern Brazilian coastal area from 5500 to 1400 14C yr BP deduced from charcoal analysis. Rev Palaeobot Palynol 110(1-2):111-138. https://doi.org/10.1016/s0034-6667(00)00004-x

Scheel-Ybert R, Caromano CF, Azevedo LW (2016) Of forests and gardens: landscape, environment, and cultural choices in Amazonia, southeastern and southern Brazil from c. 3000 to 300 cal yrs BP. Cad LEPAARQ 13(25):425-458. https://doi.org/10.15210/lepaarq.v13i25.7502

Scheel-Ybert R, Eggers S, Wesolowski V, Petronilho CC, Boyadjian CHC, DeBlasis PAD, Barbosa-Guimarães M, Gaspar MD (2003) Novas perspectivas na reconstituição do modo de vida dos sambaquieiros: uma abordagem multidisciplinar. Rev Arque 16(1):109-137. https:// doi.org/10.24885/sab.v16i1.182

Scheel-Ybert R, Gaspar MD (2014) Anthracological research on the Brazilian Coast: paleoenvironment and plant exploitation of sambaqui moundbuilders. In: Madella M, Lancelotti C, Savard M (eds) Ancient plants and people: contemporary trends in archaeobotany. The University of Arizona Press, Tucson, pp 237-262

Scheel-Ybert R, Solari ME (2005) Análise dos macrorrestos vegetais do setor oeste: antracologia e carpología. In: Vialou ÁV (ed) Pré-história do Mato Grosso, vol 1. Santa Elina. EDUSP, São Paulo, pp 139-147

Shepard GH Jr, Clement CR, Lima HP, Mendes dos Santos G, Moraes CP, Neves EG (2020) Ancient and traditional agriculture in South America: tropical lowlands. Encyclopedia of agriculture and the environment. Oxford University Press, New York. https://doi.org/10.1093/ acrefore/9780199389414.013.597 
Shepard GH Jr, Ramirez H (2011) "Made in Brazil”: human dispersal of the Brazil Nut (Bertholletia excelsa, Lecythidaceae) in ancient Amazonia. Econ Bot 65(1):44-65. https://doi.org/10.1007/ s12231-011-9151-6

Shock M, de Paula Moraes C, da Silva Belletti J, Lima M, da Silva FM, Lima LT, Cassino MF, de Lima AMA (2014) Initial contributions of charred plant remains from archaeological sites in the Amazon to reconstructions of historical ecology. Paper presented at the 3er Encuentro Internacional de Arqueología Amazónica, Quito, Ecuador,

Shock MP (2010) Holocene hunter-gatherer plant use and foraging choice: a test from Minas Gerais, Brazil. PhD thesis, University of California, Santa Barbara

Shock MP, Kipnis R, Bueno L, Silva FM (2013) A chronology of the introduction of domesticated plants in Central Brazil. Tipiti 11(2):52-59

Shock MP, Moraes CP (2019) A floresta é o domus: a importância das evidências arqueobotânicas e arqueológicas das ocupações humanas amazônicas na transição Pleistoceno/ Holoceno. Bol Mus Para Emílio Goeldi Cien Hum 14(2):263-289. https://doi.org/10.1590/198 1.81222019000200003

Silva FM, Shock MP, Neves EG, Scheel-Ybert R (2016) Vestígios macrobotânicos carbonizados na Amazônia Central: o que eles nos dizem sobre as plantas na pré-história? Cad LEPAARQ 13(25):366-385. https://doi.org/10.15210/lepaarq.v13i25.7369

Smith BD (2012) A cultural niche construction theory of initial domestication. Biol Theory 6(3):260-271. https://doi.org/10.1007/s13752-012-0028-4

Smith M, Fausto C (2016) Socialidade e diversidade de pequis (Caryocar brasiliense, Caryocaraceae) entre os Kuikuro do alto rio Xingu (Brasil). Bol Mus Para Emílio Goeldi Cien Hum 11(1):87-113. https://doi.org/10.1590/1981.81222016000100006

Staller JE, Carrasco MD (2010) Pre-Columbian foodways in Mesoamerica. In: Staller JE, Carrasco MD (eds) Pre-Columbian foodways: interdisciplinary approaches to food, culture, and markets in ancient Mesoamerica. Springer, New York, pp 1-20

Tamanaha EK (2018) Um panorama comparativo da Amazônia no ano 1000. Doctoral thesis, Universidade de São Paulo, São Paulo

Thomas E, van Zonneveld M, Loo J, Hodgkin T, Galluzzi G, van Etten J (2012) Present spatial diversity patterns of Theobroma cacao L. in the Neotropics reflect genetic differentiation in Pleistocene refugia followed by human-influenced dispersal. PLoS One 7(10):e47676. https:// doi.org/10.1371/journal.pone.0047676

Troufflard J, Alves DT (2019) Uma abordagem interdisciplinar do sítio arqueológico Cedro, baixo Amazonas. Bol Mus Para Emílio Goeldi Cien Hum 14(2):553-580. https://doi.org/10.159 0/1981.81222019000200015

Vialou D, Benabdelhadi M, Feathers J, Fontugne M, Vialou AV (2017) Peopling South America's centre: the late Pleistocene site of Santa Elina. Antiquity 91(358):865-884. https://doi. org/10.15184/aqy.2017.101

Villagran XS (2010) Geoarqueologia de um sambaqui monumental: estratigrafias que falam. Annablume/Fapesp, São Paulo

Walker M, Head MJ, Berkelhammer M, Björck S, Cheng H, Cwynar L, Fisher D, Gkinis V, Long A, Lowe J (2018) Formal ratification of the subdivision of the Holocene series/Epoch (quaternary system/period): two new Global Boundary Stratotype Sections and Points (GSSPs) and three new stages/subseries. Episodes 41(4):213-223. https://doi.org/10.18814/epiiugs/2018/018016

Watling J, Almeida F, Kater T, Zuse S, Shock MP, Mongeló G, Bespalez E, Santi JR, Neves EG (2020) Arqueobotânica de ocupações ceramistas na Cachoeira do Teotônio. Bol Mus Para Emílio Goeldi Cien Hum 15(2). https://doi.org/10.1590/2178-2547-bgoeldi-2019-0075

Watling J, Iriarte J, Mayle FE, Schaan D, Pessenda LCR, Loader NJ, Street-Perrott FA, Dickau RE, Damasceno A, Ranzi A (2017) Impact of pre-Columbian "geoglyph" builders on Amazonian forests. Proc Natl Acad Sci U S A 114(8):1868-1873. https://doi.org/10.1073/pnas.1614359114

Watling J, Saunaluoma S, Pärssinen M, Schaan D (2015) Subsistence practices among earthwork builders: Phytolith evidence from archaeological sites in the southwest Amazonian interfluves. J Arch Sci Rep 4:541-551. https://doi.org/10.1016/j.jasrep.2015.10.014 
Watling J, Shock MP, Mongelo GZ, Almeida FO, Kater T, Oliveira PE, Neves EG (2018) Direct archaeological evidence for southwestern Amazonia as an early plant domestication and food production centre. PLoS One 13(7):e0199868. https://doi.org/10.1371/journal.pone.0199868

Wesolowski V, de Souza SMFM, Reinhard K, Ceccantini G (2007) Grânulos de amido e fitólitos em cálculos dentários humanos: contribuição ao estudo do modo de vida e subsistência de grupos sambaquianos do litoral sul do Brasil. Rev Mus Arqueo Etnol (17):191-210. https://doi. org/10.11606/issn.2448-1750.revmae.2007.89773

Wesolowski V, de Souza SMFM, Reinhard KJ, Ceccantini G (2010) Evaluating microfossil content of dental calculus from Brazilian sambaquis. J Arch Sci 37(6):1326-1338. https://doi. org/10.1016/j.jas.2009.12.037

Zarrillo S, Gaikwad N, Lanaud C, Powis T, Viot C, Lesur I, Fouet O, Argout X, Guichoux E, Salin F, Solorzano RL, Bouchez O, Vignes H, Severts P, Hurtado J, Yepez A, Grivetti L, Blake M, Valdez F (2018) The use and domestication of Theobroma cacao during the mid-Holocene in the upper Amazon. Nat Ecol Evol 2:1879-1888. https://doi.org/10.1038/s41559-018-0697-x

Zuse S (2014) Variabilidade cerâmica e diversidade cultural no alto rio Madeira, Rondônia. Doctoral thesis, Universidade de São Paulo, São Paulo 